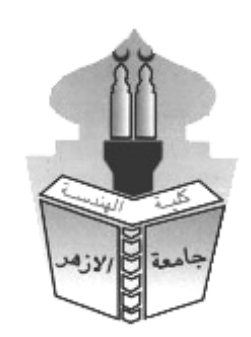

\title{
EMERGENCY SHELTER IN CASE OF DIRECT AND INDIRECT DISASTERS (COMMUNITY-BASED) (AN APPLIED STUDY ON THE CITY OF AL-ARISH - NORTH SINAI)
}

\author{
Ensaf Osama Ali*1, Ahmad Saad Dabour ${ }^{2}$ and Mohamed Hassan Khalil ${ }^{2}$ \\ ${ }^{1}$ Department of architecture ,High Institute for Engineering \&Technology in Al-Arishs, Egypt \\ ${ }^{2}$ Department of architecture, Faculty of Eng. of Al-Azhar University ,Nasr city ,Cairo ,Egypt \\ *Corresponding author E-mail : ensafosama90@gmail.com
}

\begin{abstract}
The world has always faced various crises and problems that developed and got worse thereafter to be a disaster, which resulted in the destruction of humanity and threatening its stability, much less the material and moral damages. Disasters affect various parts of the world. They are divided into natural disasters such as earthquakes, floods, high temperatures, droughts, etc., and man-made disasters such as wars, pollution, destruction, epidemics, etc., leaving behind destroyed buildings and homeless people. The kinds of disasters have increased and new ones, indirectly affecting people and society and harming its equilibrium, have appeared over time. They are called the "Indirect community disasters," which in turn cause damage no less serious than other natural or man-made disasters.

Arab countries in general, and Egypt in particular, suffer from many indirect disasters such as drug addiction, unemployment, street children, congestion and overcrowding, illiteracy, dropping out of education, population displacement and others. In the event of a disaster, different emergency shelter techniques are urgently resorted to in order to reduce the aggravation of the disaster and to shelter those affected. Also, in the case of indirect (community) disasters, emergency sheltering techniques should be applied to control the disaster and reduce its aggravation. Urgent shelter is not limited to providing temporary housing for the homeless, but its comprehensive concept is "the Urgent containment economically, socially, physically and educationally." Thus, if states are able to apply the concept of emergency sheltering in the right sense properly in the case of (direct and indirect) disasters, they will ensure the stability and safety of their people.
\end{abstract}

This paper discusses the direct and indirect disasters and the difference between them, and the urgent shelter used in disasters of all kinds. It also deals with the disasters that hit the governorate of North Sinai, specifically the city of Al-Arish since 2010 until 2017 (namely Al-Arish Floods 2010), as a direct disaster, and the displacement of the people of Rafah and Sheikh Zuweid as an indirect disaster.

KEYWORDS: Disasters , Emergency Shelter, Community Disasters, Direct Disasters, Indirect Disasters, Al-Arish City, North Sinai Governorate, Al-Arish Floods, Population Displacement, Rafah City, Sheikh Zowaid City. 
الإيواء العاجل في حالات الكوارث المباشرة و غير المباشرة (المجتمعية)

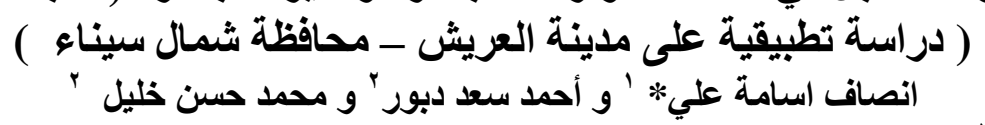

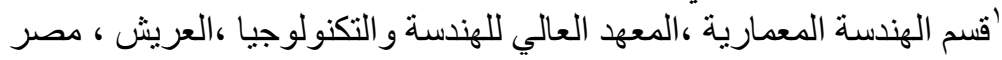

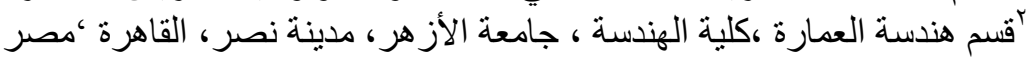

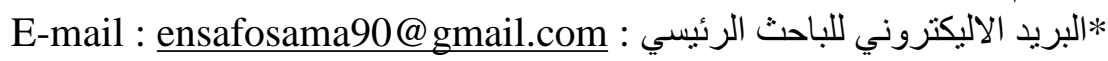

\section{ملخص البحث}

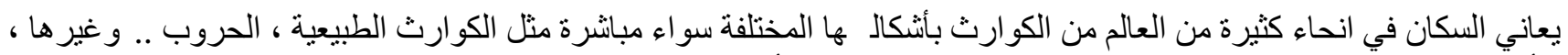

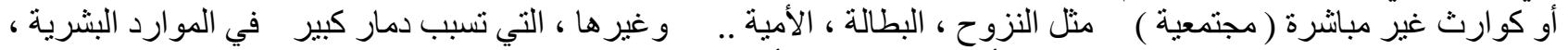

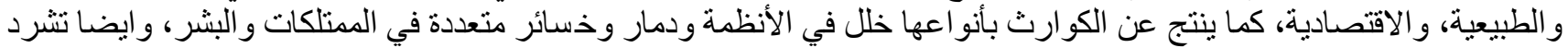

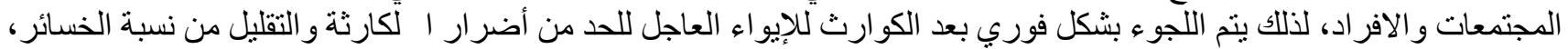

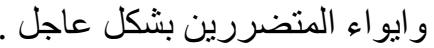

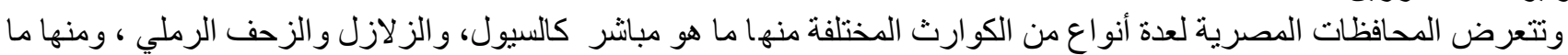

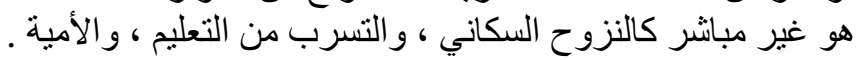

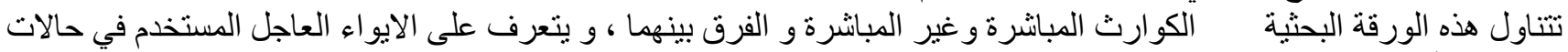

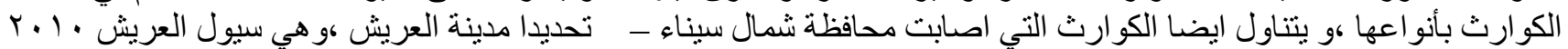

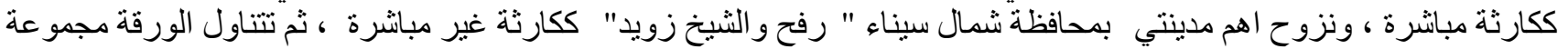
النتائج التي تم التوصل ونز اليها وبعض اهن التوصيات اللازمة لمعالجة مثل هذه الامور.

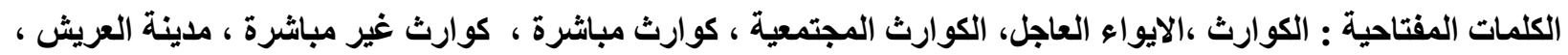

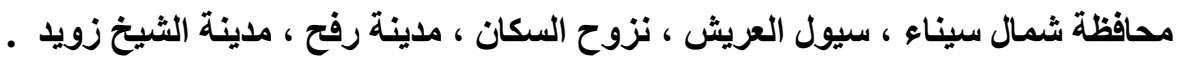

مقدمة

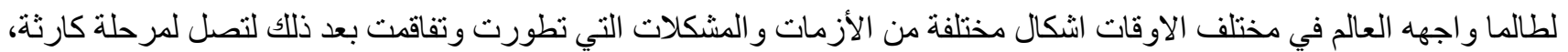

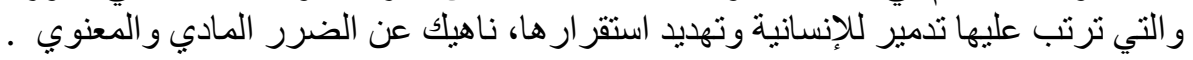

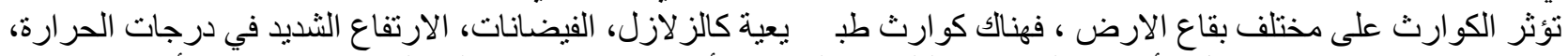

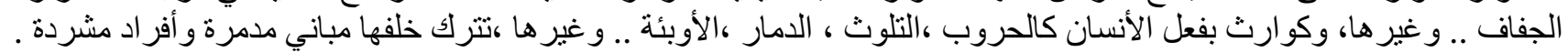

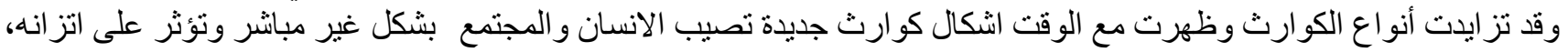

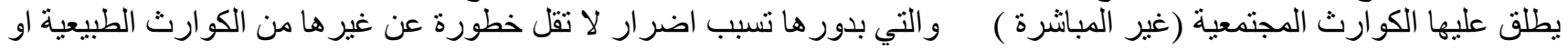

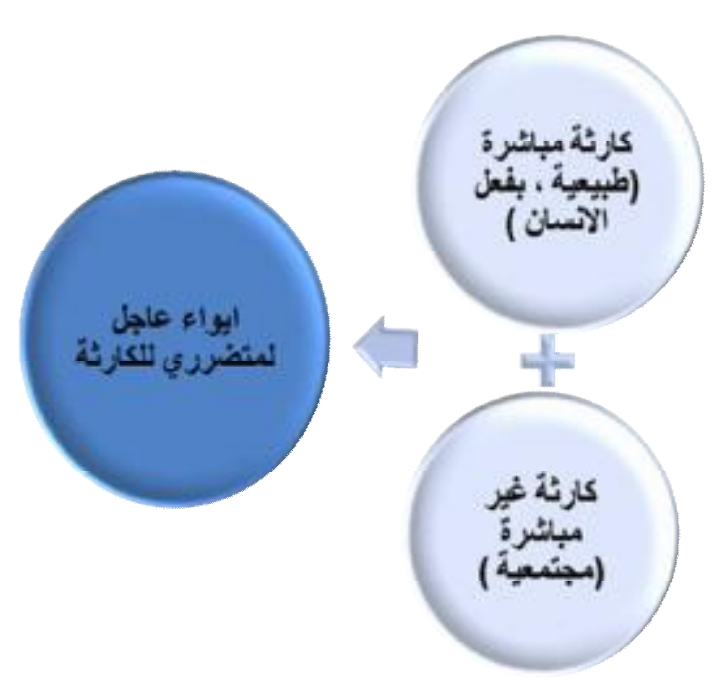

كل (1) استخدام الايواء العاجل في حالة الكوارث المباشرة وغي

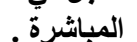

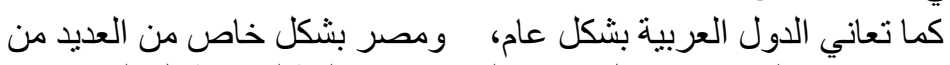

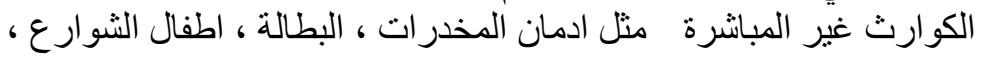

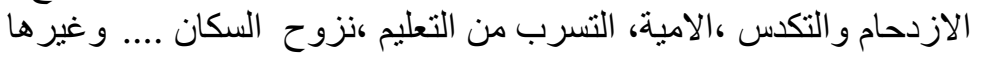

في حالة وقوع كارثة يتم بشكل طارئ وفوري اللجو ء لأساليب الايو اء اء كاء

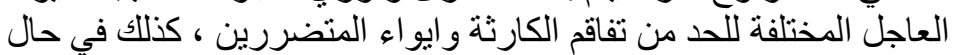

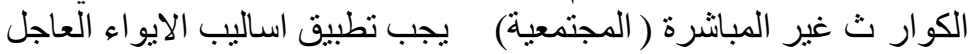

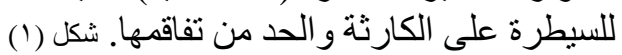

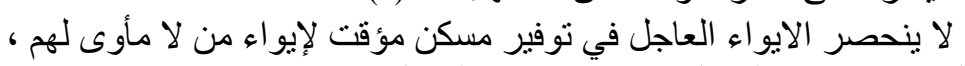

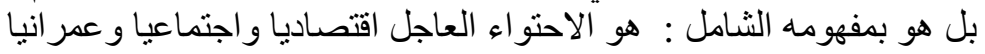

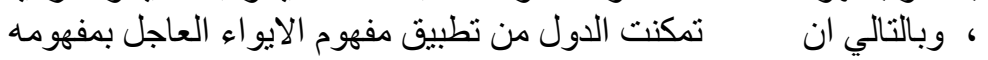

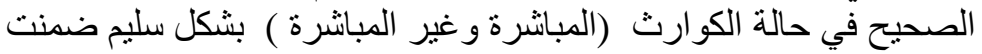

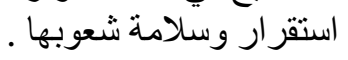

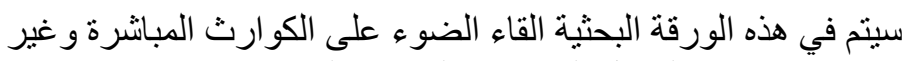

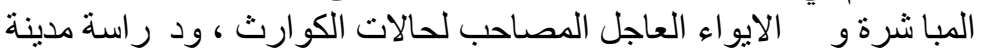
العريش، وكذللك رفح و الثيخ زويد في محافظة شمال سيناء كحالة در اسية. 
يتم تطبيق الايو اء العاجل في حال الكو ارث المختلفة كالز لازل و السيول و غير ها لإيو اء العاء المتضررين ومقاومة الكارثة ، كذللك في حالة

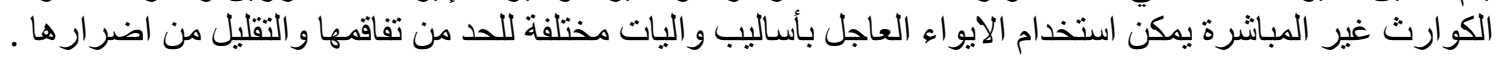

$$
\begin{aligned}
& \text { أهداف البحث } \\
& \text { • التعرف على اساليب الايو اء العاجل في مصر. }
\end{aligned}
$$

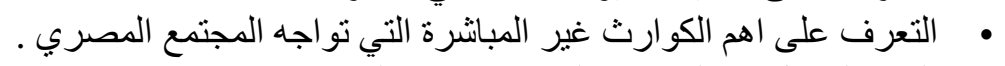

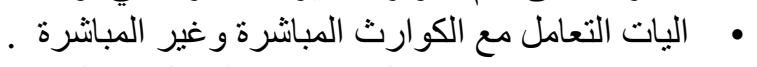

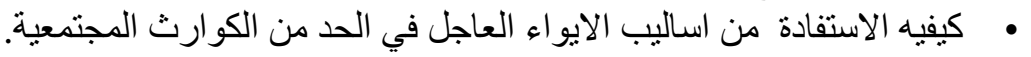

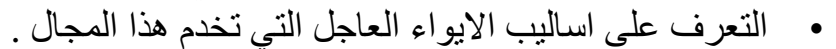

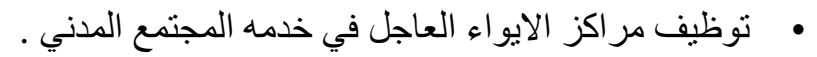

منهجية البحث.

الدر اسة النظرية (الاستقر ائي ) : يعتمد هذا الجزء على على جمع البيانات و المعلومات من المر اجع العلمية و الابحاث و الدوريات

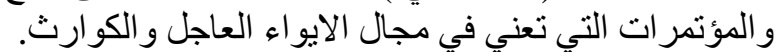

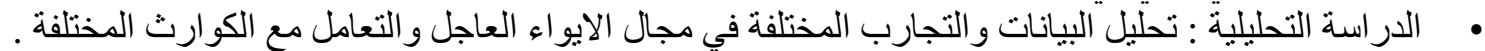

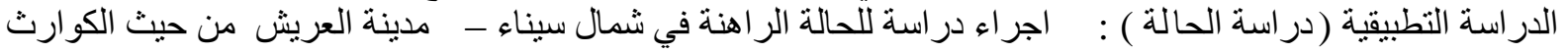
المبانرة وغير المباشرة ، و واساليب الايو اء العاجل المستخدمة ،وتحليلها وتقييمها من خلال العناصر التي تم التوصل التهل اليها في الدر اسة النظرية .

محتوي البحث.

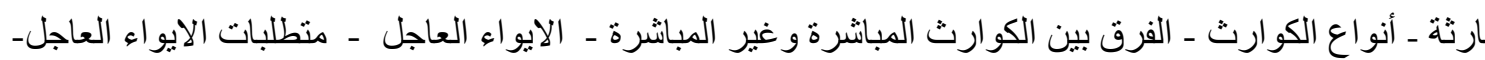

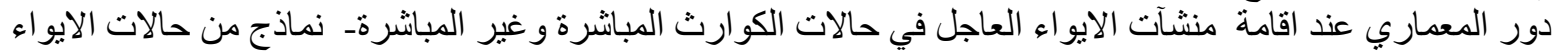

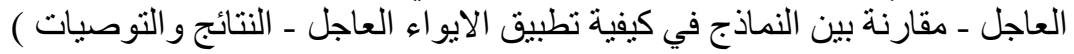

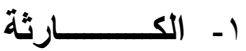

ويتخدم مصطلح كارثة كتعبير على مصيبة هائلة ،لا يمكن التعايش معها لأنها أتت مخلة للاتز ان وتتطلب تدخل عاجل

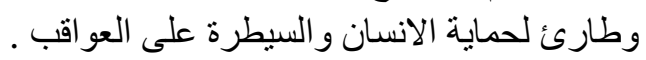

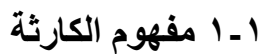

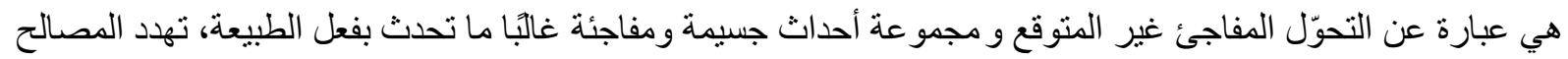

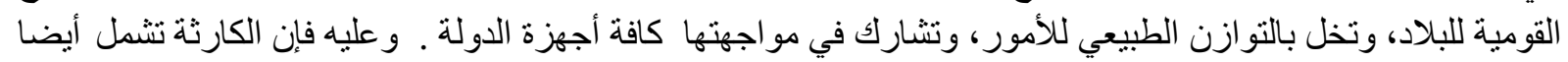

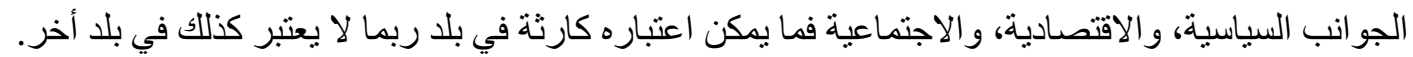

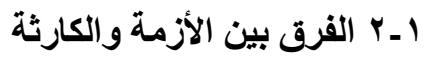

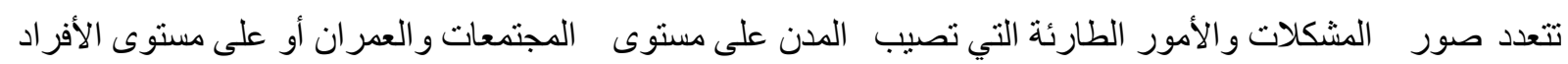

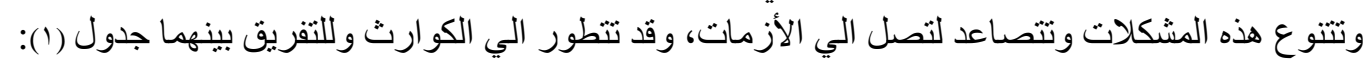

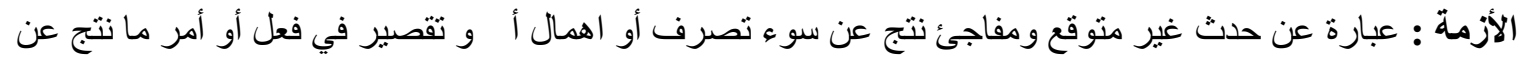

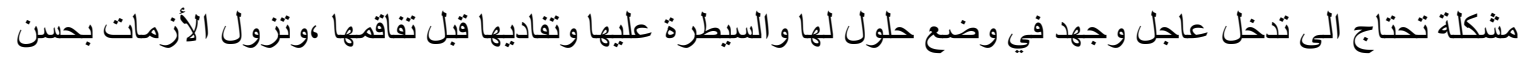

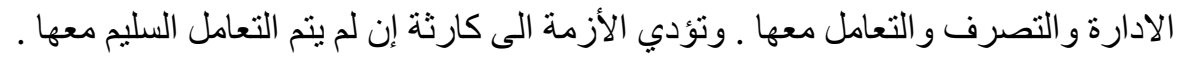

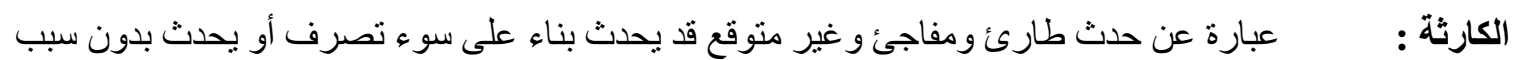

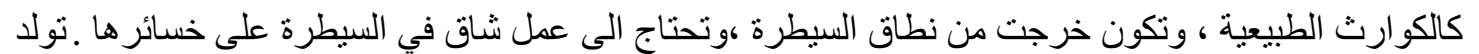

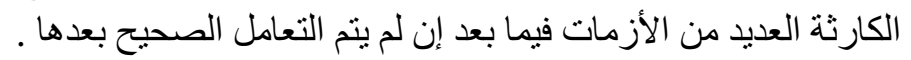


جدول ( ) الفرق بين الأزمة والكارثة .

\begin{tabular}{|c|c|c|}
\hline 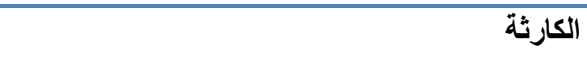 & الأزمة & عنصر المقارنة \\
\hline 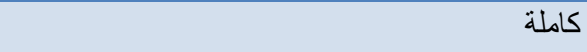 & تصاعدية & 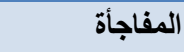 \\
\hline بشرية ومادية وطبيعية واجتماعية & معنوية ،مادية & الخسائر \\
\hline طبيعية أو بفعل الانسان & بفعل الانسان & الأسباب \\
\hline صعبة التنبؤ & ممكنة التنبؤ & التنبؤ بوقوعها \\
\hline معلنة & ت ت تكون سرية غالبا & الإعلان عنها \\
\hline لا يمكن السيطرة عليها ولكن يمكن التقليل من الخسائر & يتم السيطرة عليها ومعالجتها سريعا & السيطرة عليها \\
\hline على المستوى المحلي و الإقليمي و الدولي & على المستوى الداخلي & المستوى \\
\hline الكارثة الواحدة تؤدي الى أزمات متعددة & الأزمة الو احدة تؤدي الى كارثة & 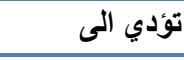 \\
\hline
\end{tabular}

\section{بـ - أنواع الكوارث}

\section{تنقسم الكوارث الى قسمين : كوارث مباشرة ، وكوارث غير مباشرة (مجتمعية ) .}

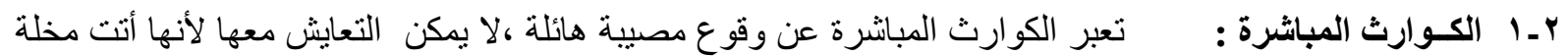

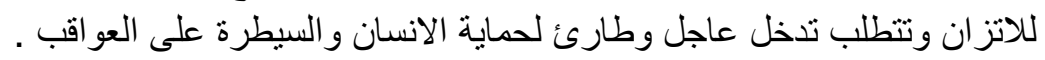

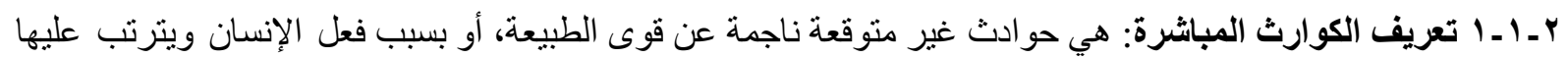

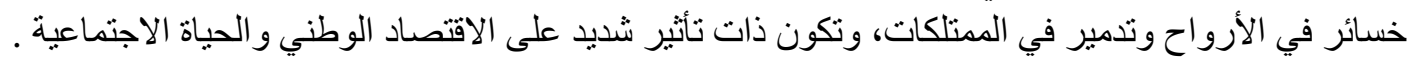

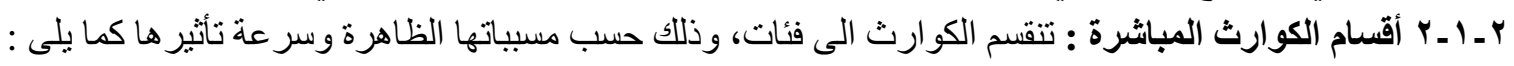

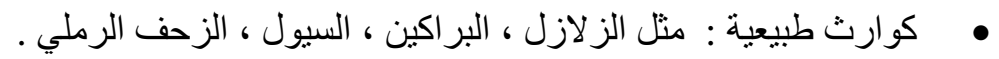

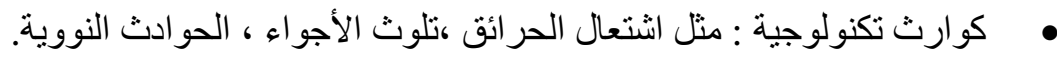

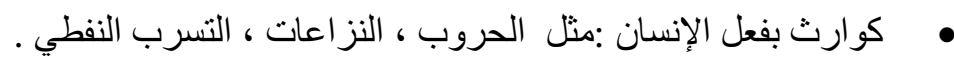
r r r r r الكوارث غير المباشرة (المجتمعية ):

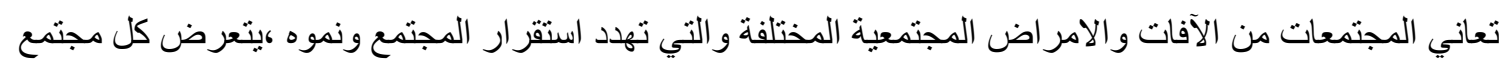

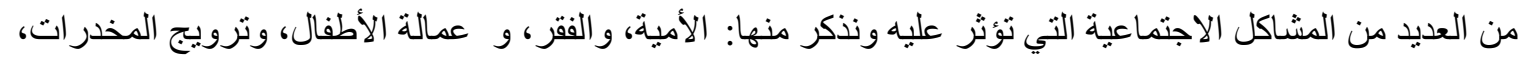
و والتسرب المدرسي و غير هن العنا.

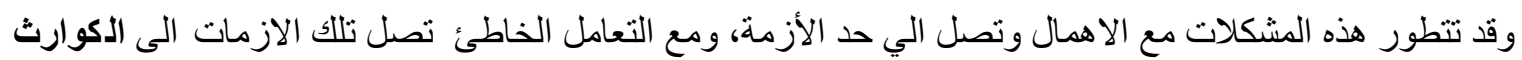

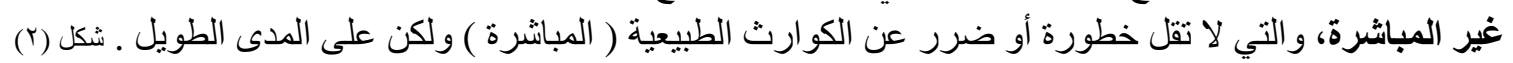

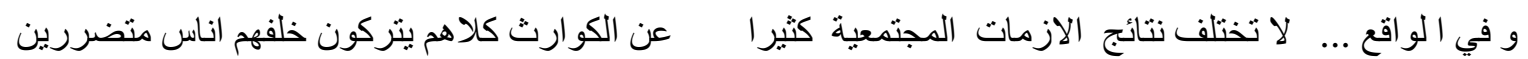

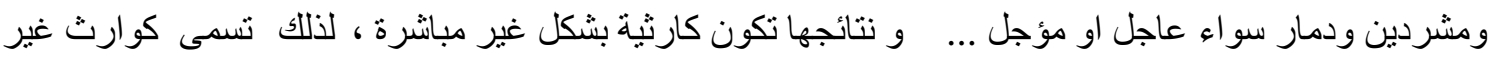
هي الخطر الذي يصيب ويؤثر سلبا على المجتمع نتيجة تفاقم المشكلات المجتمعية بو اسطة الإهمال و التعامل الخاطئ

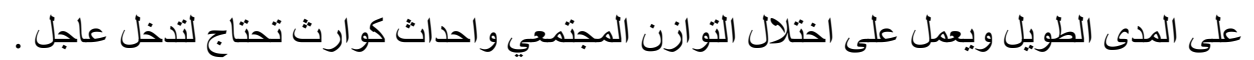

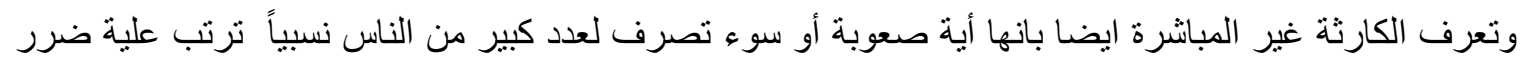

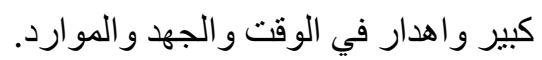
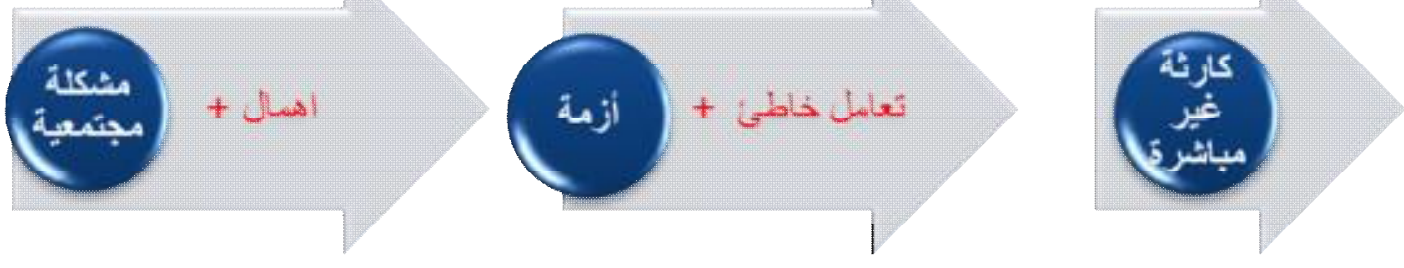

شكل (ץ) تكون الكارثة غير المباثرة. 


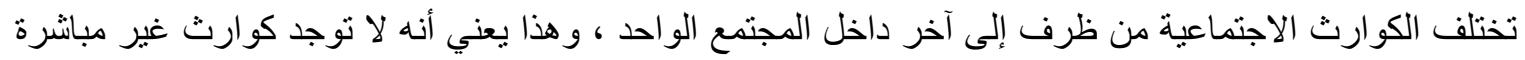

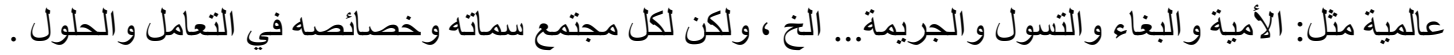

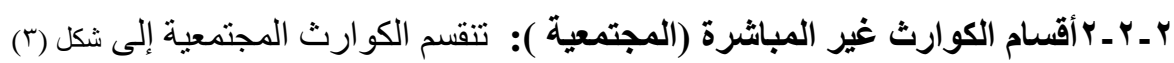

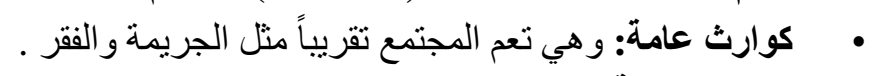

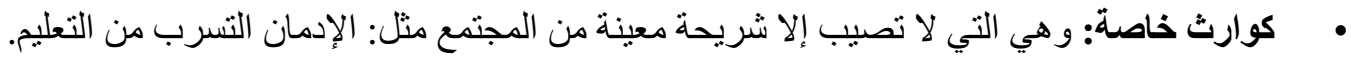

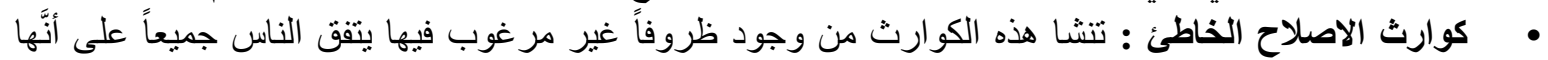

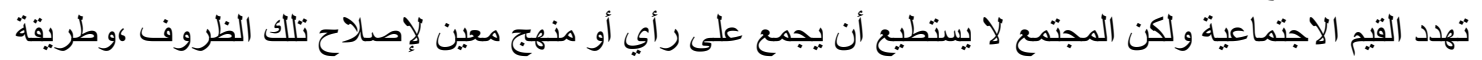

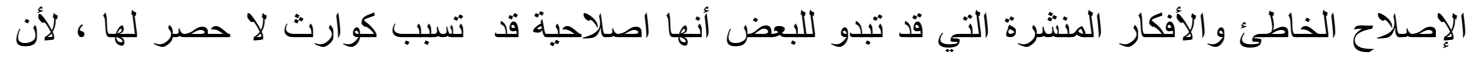

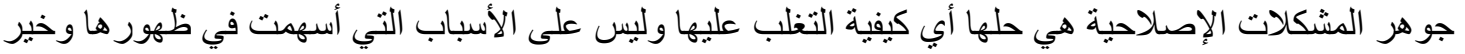

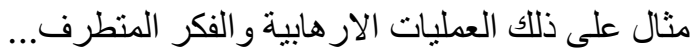

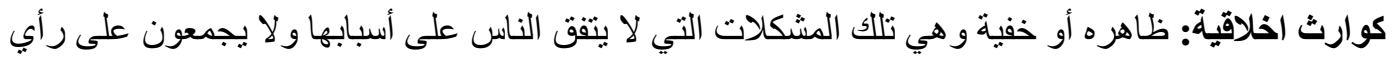
حولها بسبب الغموض والإبهام الذي يكتف القيم الاجتماعبة المتعارف علئها بلينهم.

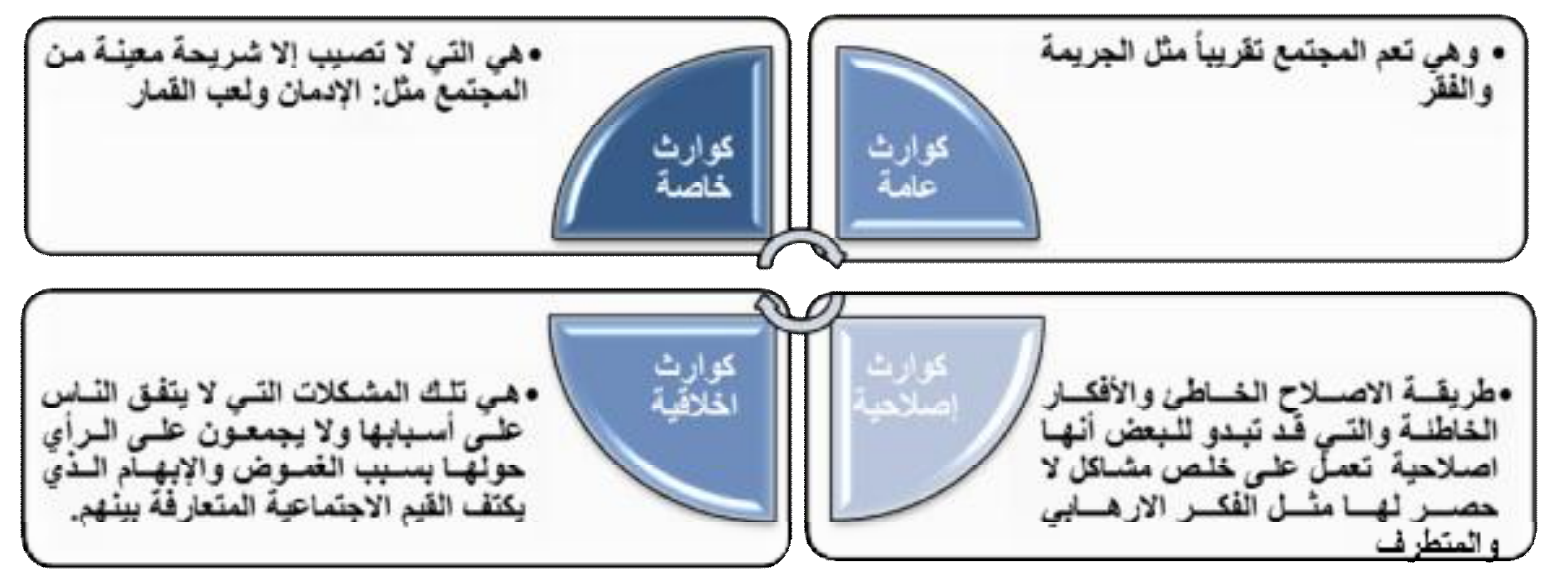

$$
\text { شكل (ب) اقسام الكوارث غيز المباشرة. }
$$

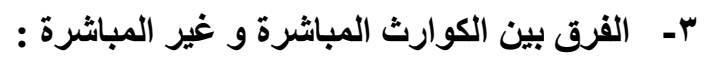

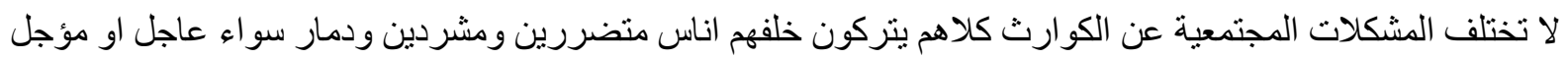

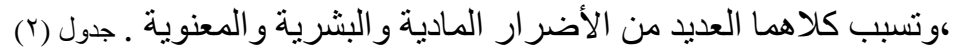

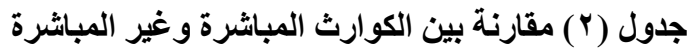

\begin{tabular}{|c|c|c|}
\hline الكوارث غير المباشرة & الكوارث المباشرة & عنصر المقارنة \\
\hline تكون على المدى البعيد & بعضها مفاجئ & 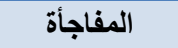 \\
\hline بشرية ومادية وطبيعية واجتماعية & بشرية ومادية وطبيعية و اجتماعية & الخسائر \\
\hline بإهمال الانسان & بفعل الانسان و الطبيعة و التكنولوجيا & الأسباب \\
\hline صعبة التنبؤ & مكنة التنبؤ & التبؤ بوقوعها \\
\hline يصعب الاعلان عنها وتكون مخفية & معلنة وو اضحة & الإعلان عنها \\
\hline لا يمكن السيطرة عليها بسهولة & يتم السيطرة عليها ومعالجتها سريعا & السيطرة عليها \\
\hline على المستوى المجتمع المحلي & على المستوى العالمي و المحلي & المستوى \\
\hline
\end{tabular}


ـ - الإيواء العاجل

يعرف الإيواء العاجل هو ذلك المأوى الذي توفره الدول لمواطنيها أو مواطني الدول الأخرى ، ألوان كبديل مؤقت أو دائم لحين

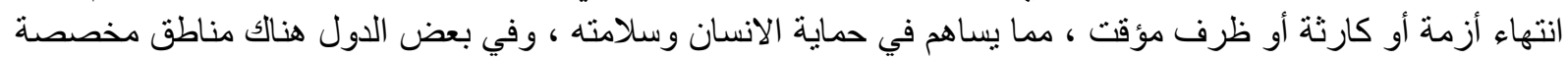

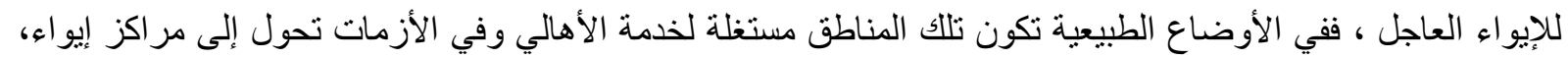

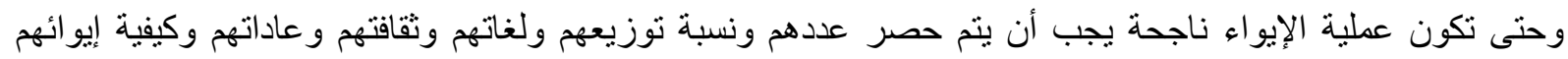

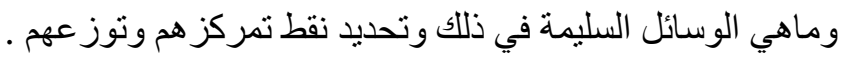

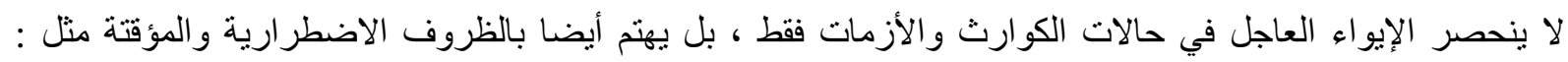

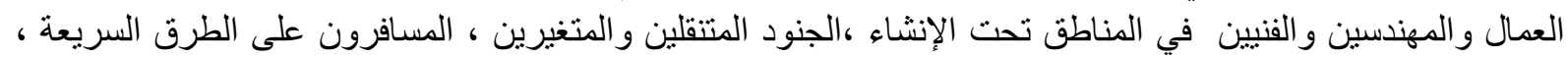

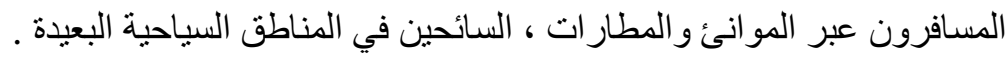

هـ المتطلبات الواجب توفرها عند اقامة الايواء العاجل :

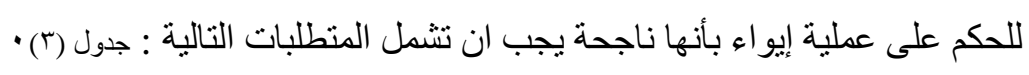

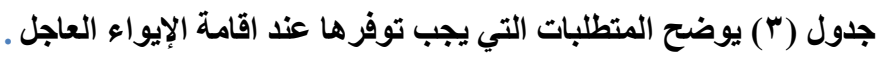

\begin{tabular}{|c|c|}
\hline التوضيح & مطلب \\
\hline وجود تتظيم اجتماعي يشعر فيه الفرد بالانتماء اليه ويتسم بالثبات و الاستقر ار والدوام وتتحدد فيه الحقوق & اجتماعي \\
\hline تشمل تدابير الحماية التي تؤهل الفرد و المجتمع للحصول على حاجاته الأساسية خاصة في الظروف التي يو اجه فيها & اقتصادي \\
\hline تحقق أقصى حماية للبيئة بكافة جو انبها من البر والبحر والذهو اء ومنع أي تعد عليها قبل حدوثه و اتخاذ الاجر اءات & بيئي \\
\hline هو الأمن الثخصي و الطمأنينة و إنثباع الحاجات السيكولوجية من الحب و المحبة و العطاء و الانتماء و المكانة وتقدير & نفسي \\
\hline هو قدرة المجتمع على توفير الاحتياجات الغذائية الاساسية للفرد و المجتمع وضمان الحد الأدنى من تللك الاحتياجات & غذائي \\
\hline 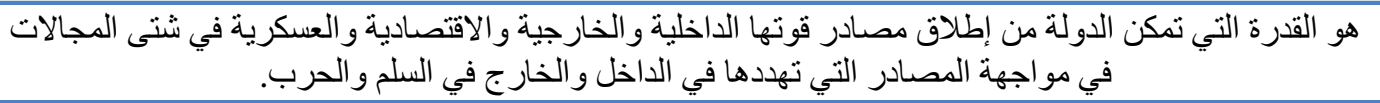 & قومي \\
\hline 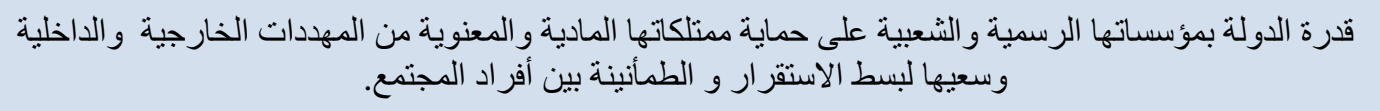 & وطني \\
\hline 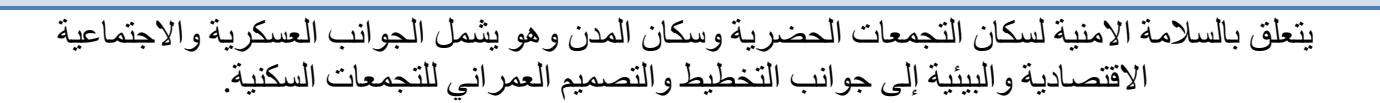 & حضري \\
\hline
\end{tabular}

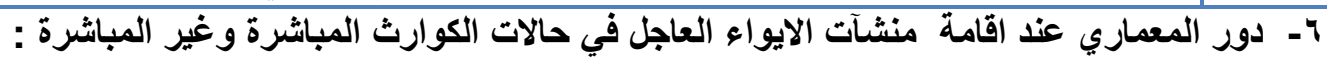

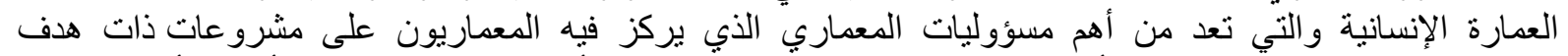

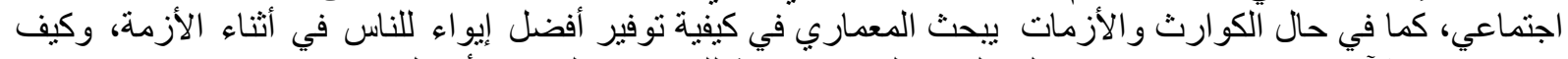

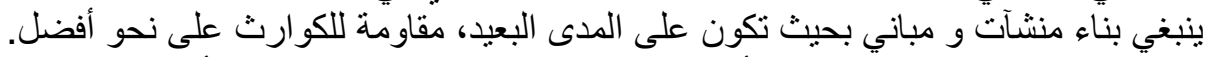

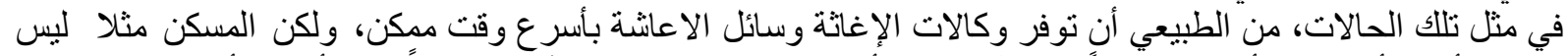

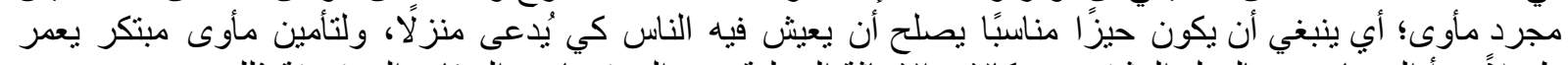

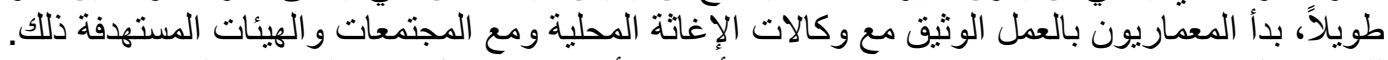

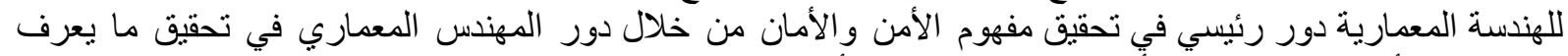

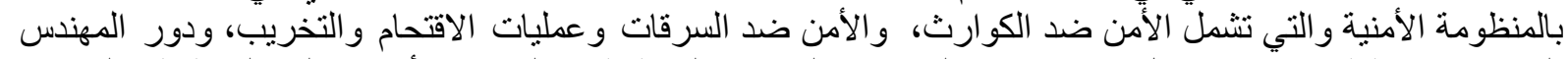

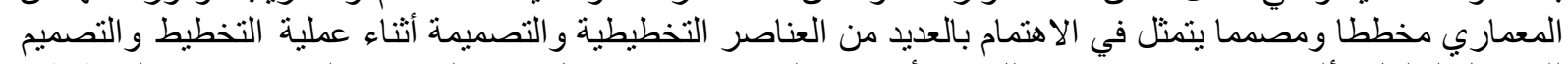

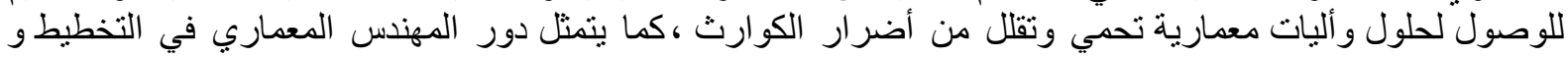

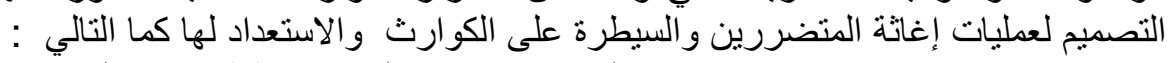

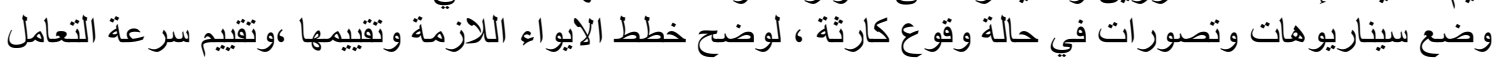
والاستجابة للكارثة . 


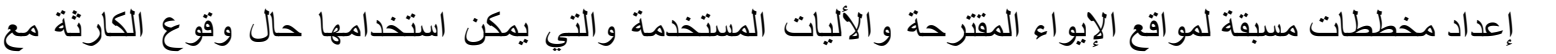

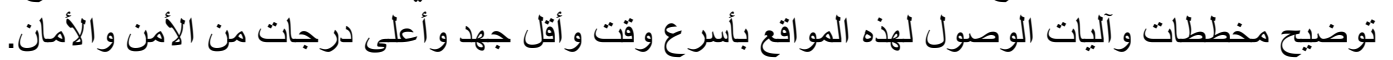
تخطيطوتصميم مواقع واساليب ايواء الكارثة غير المباثرة بحيث تعزز الترابط الاجتماعي بين المنضررين من التران

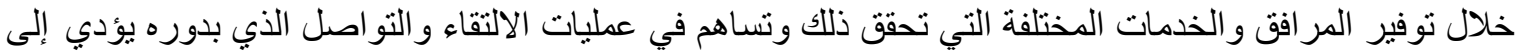
الثعور بالأمن و الأمان. تخطيطوتصميم مواقع الإيواء بحيث توفر كافة الاحتياجات الإنسانية داخل المأوى منلما كانت تتوفر للأفراد في

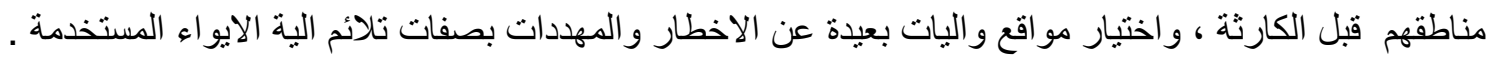

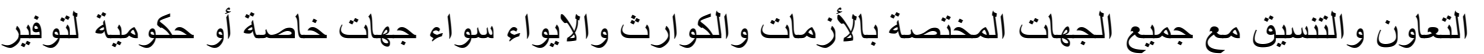

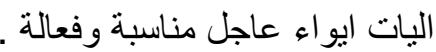

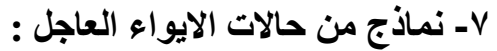

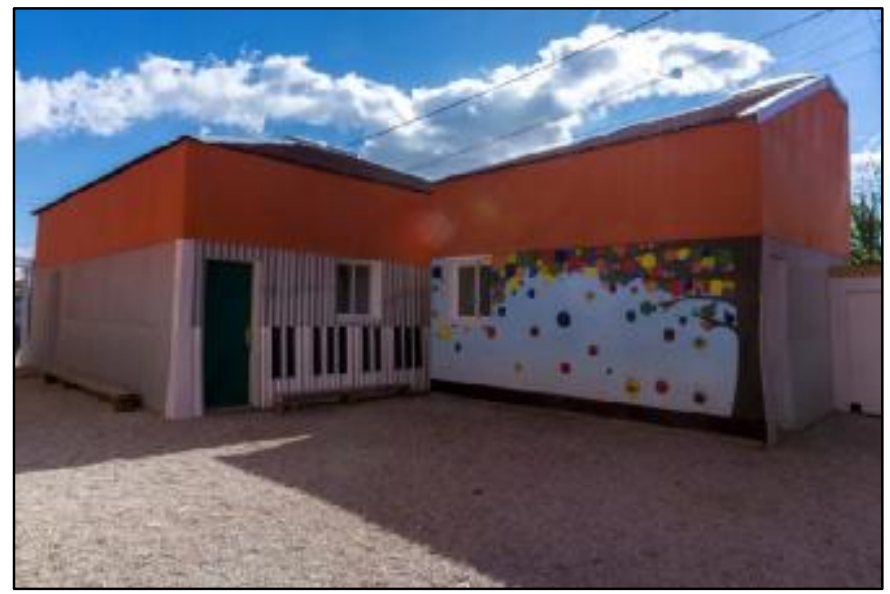

شكل ( ع ) مدرسة الجارحية ، المصدر : مدرسة الجارحية ، موقع جائزة الاغا

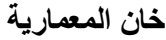

https://www.akdn.org/architecture/project/jarahieh-
يعاني السكان في العالم من أنثكال مختلفة من الكوارث

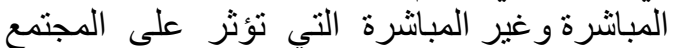

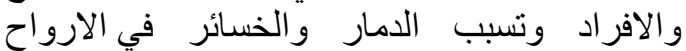

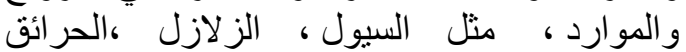

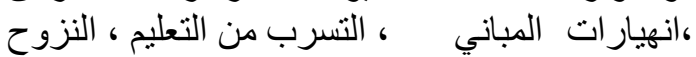

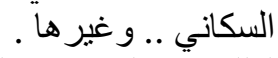
للالك يقدم البجث اساليب الايواء العاجل المستخدمة في مخيم الجر احية للاجئين في سهل البقاع اللبناني- لبنان البان

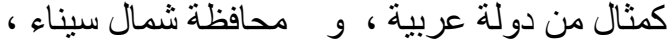
تحديدا مدينة العريش كحالة در اسية من مصر في في حالة

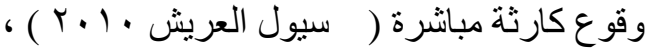
وكارثة غبر مباثرة (نزو ماثن سكان مدينتي رفح و الثيخ

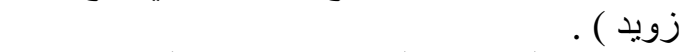

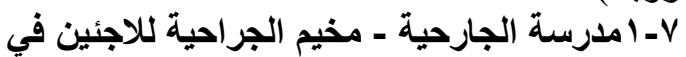

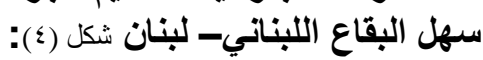

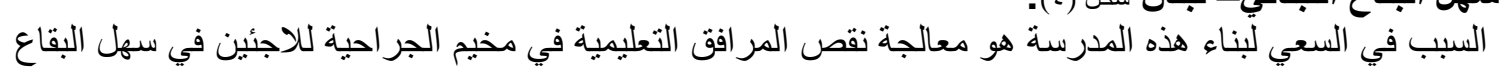

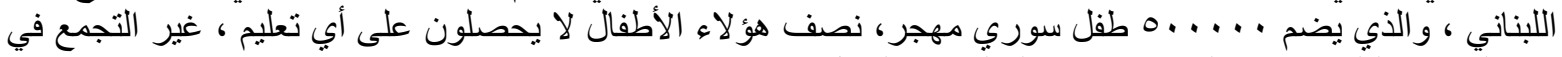

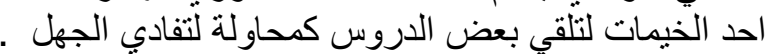

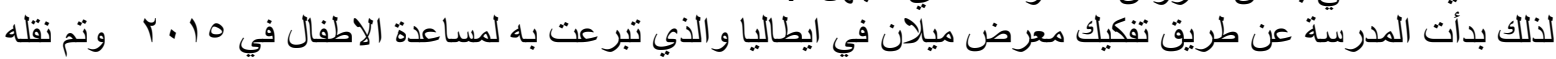

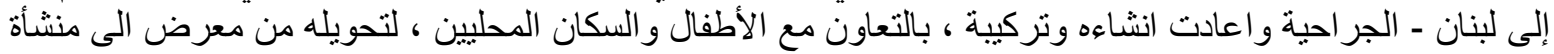

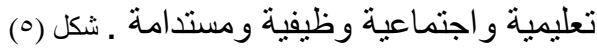
شكل (ه) : خطوات نقل المعرض وتحويلة لمدرسة (مدرسة الجارحية) .

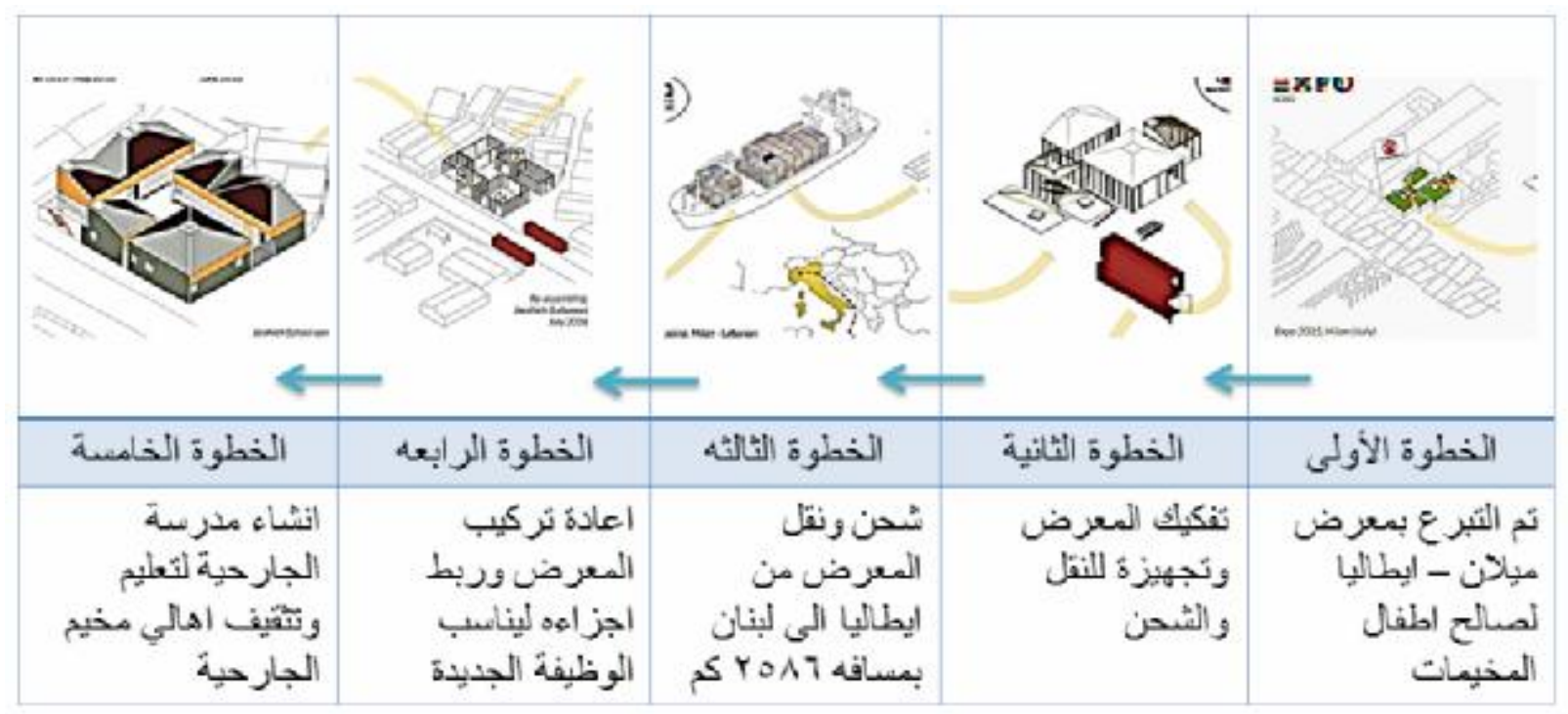




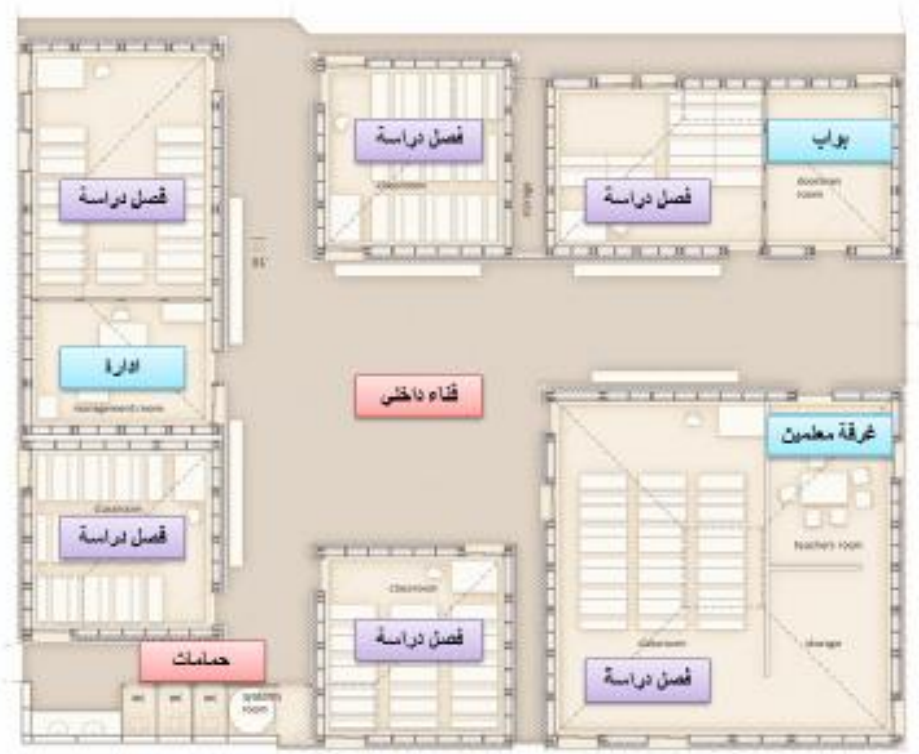

شكل (†) : مكونات المدرسة (مدرسة الجارحية) .

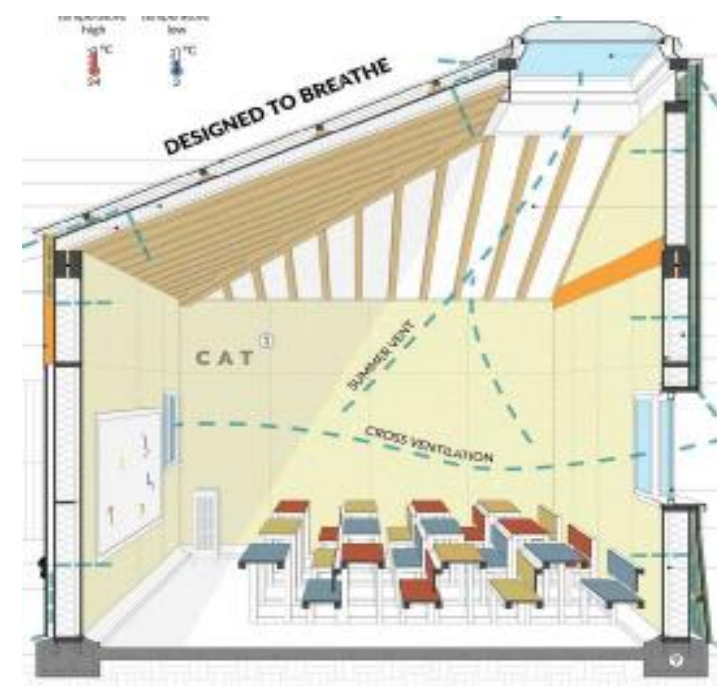

شكل (V) :الاعتماد على الاضاءه و التهوية الطبيعيه في التئي المدرسة ، المصدر : ، مدرسة الجارحية موقع جائزة الاغيا

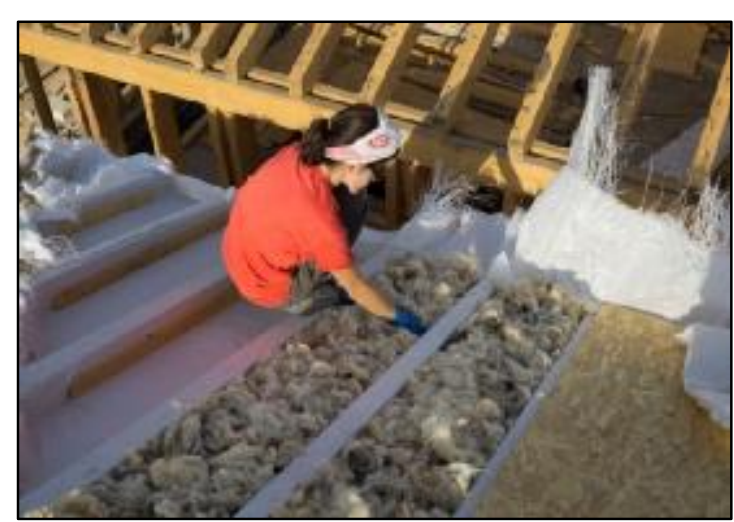

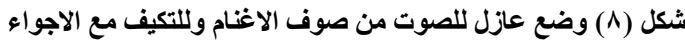

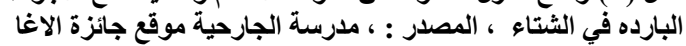

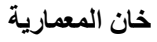

تتكون هذه المدرسة من ستة فصول در اسية ،

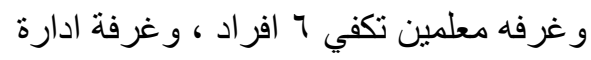

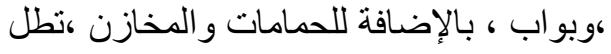

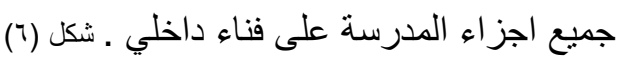
تم تصميم الفصول ذاتية التبريد عن طريق أبقاء

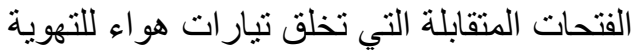

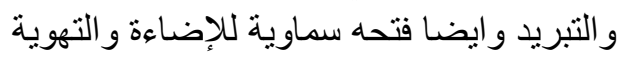

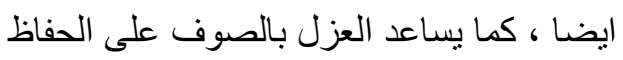

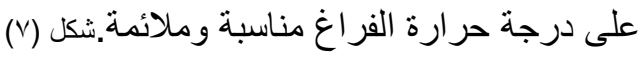
تم تنفيذ استراتيجيات بناء غير عادية بمساعدة

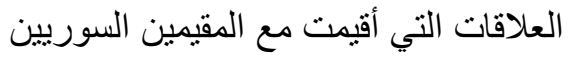

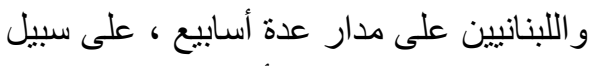

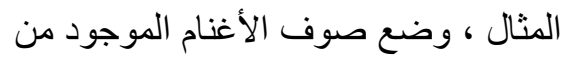

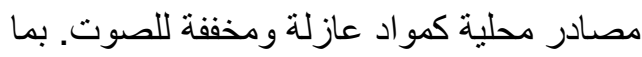

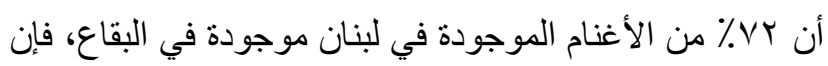
هذه الاستر اتيجية لم تكن مستدامة فحسب ، الامد بل دعمت أيضًا

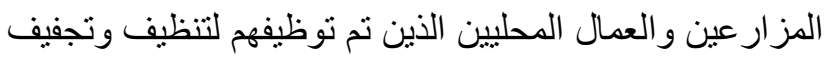
الصوف. شكل (^).

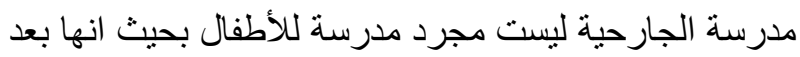

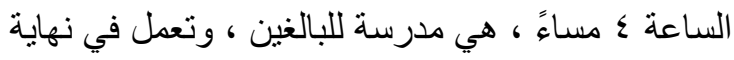

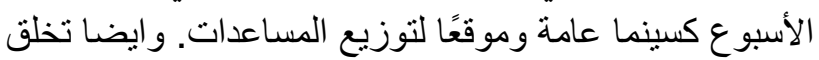

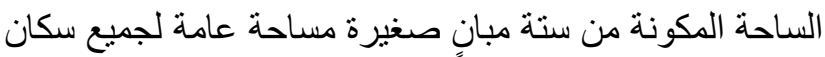

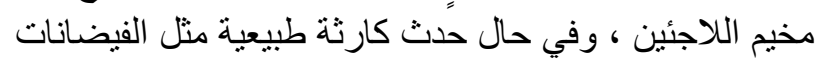

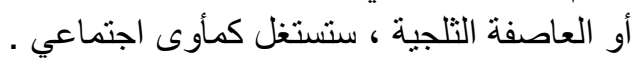

تعد مدرسة الجارحية دليلاً على حقيقة أن الإنشاءات المؤقتـة

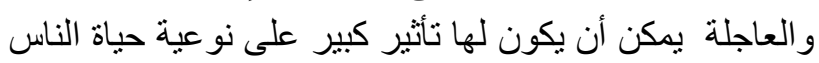

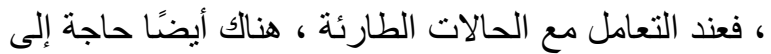

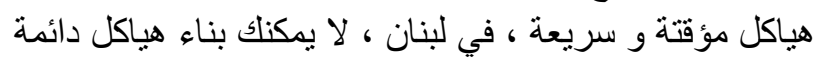

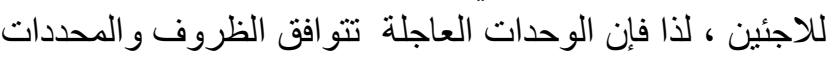

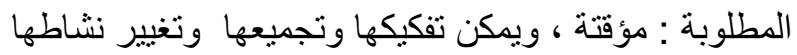

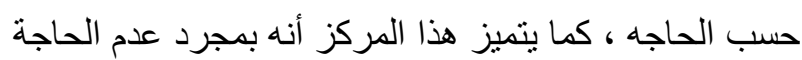

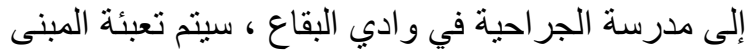

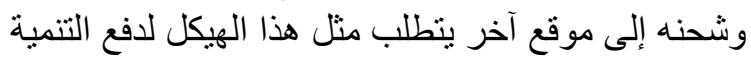

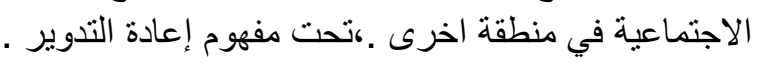




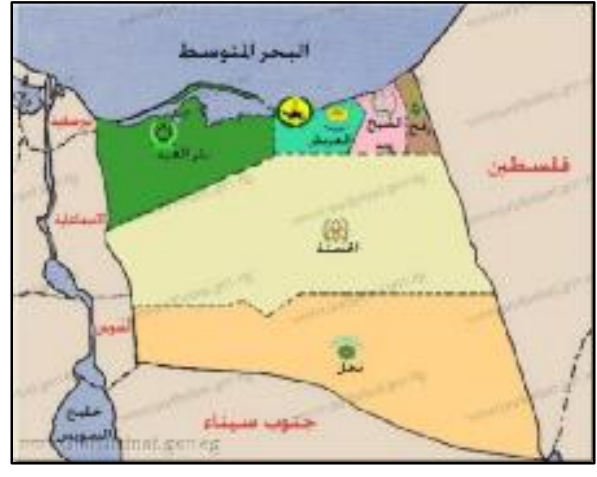

شكل (9) خريطة محافظة شمال سيناء ، المصدر : .

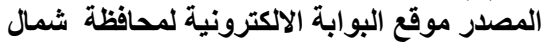

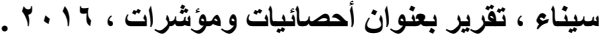
/http://www.northsinai.gov.eg

الخسانر الناتجة عن سيول هحافظة شهال سينلي

\begin{tabular}{|c|c|c|c|c|c|c|c|c|}
\hline \multirow{2}{*}{ بالغالث جنبة } & \multirow{2}{*}{ الإجصالي } & \multicolumn{5}{|c|}{ البركسـ } & \multirow[t]{2}{*}{ منصر البيان } & \multirow[t]{2}{*}{$\theta$} \\
\hline & & $\omega$ & عصة & $\infty$ & الشيهنيد & العريش & & \\
\hline ro & 。 & - & - & $r$ & • & $r$ & 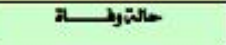 & $T$ \\
\hline . & . & . & . & . & . & • & 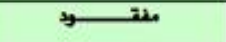 & $r$ \\
\hline 1. & 1. & 1. & . & . & . & . & المبايســـ & $T$ \\
\hline $190 . .$. & $V_{A}$. & \& & $\wedge$ & $r$ & ro & vi. & "ميلامتزل & 1 \\
\hline $171:$. & 1.87 & A. & ar & 10 & \$o & var & لمعرمثتل بالهيه & a \\
\hline noo. & $|v|$ & 1 & . & . & - & 170 & مثشومسلات & \\
\hline$\pi \xi$ & Irt & $r q$ & rr. & ro & ro & rr. & 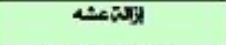 & \\
\hline . & vr & ro & ro & 。 & 1 & 17 & (3) & a \\
\hline raroo & 04.50 & rr.o & 1. & .0 & .50 & 10 & 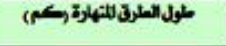 & 1 \\
\hline rEA & Ary & $1 \leqslant 9$ & $\mathrm{~m}$ & 1. & 1 & irn & 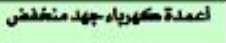 & 1. \\
\hline 9.1 & ra & - & 11 & 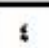 & $r$ & r. & 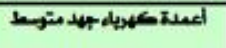 & $\pi$ \\
\hline $19 \wedge \mid$. & ITA1. & - & - & r. . & v. & $170 .$. & 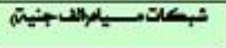 & $\bar{w}$ \\
\hline VIEO & viाo & + & . & $\cdot$ & . & VIEO & 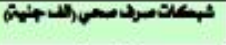 & if \\
\hline no. & ili & Ar & 10 & 4 & 1 & - & خزالنميله & प \\
\hline 0 . & 0 . & 0. & - & . & . & - & تليفوقات رلك جنيت & 10 \\
\hline r.द. & $n$ & $r$ & $r$ & $r$ & - & pa & 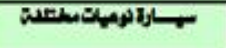 & $\pi$ \\
\hline $170 \%$ & IATA & $1 \leqslant v$ & $r .$. & ro. & $4 . \cdot$ & 111 & وله العنامر(علا) & w \\
\hline avery & rvat. & 10r. & ir... & o.. & o.. & irr.. & التجهار متمرة (علد) & u \\
\hline $1 \ldots .$. & $1 \ldots$. & $r \cdots$ & $r \ldots$ & . & - & $1 \ldots$ & 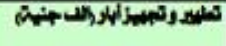 & $n$ \\
\hline $1 \ldots$. & $1 \ldots$. & . & . & . & - & $1 \ldots$. & 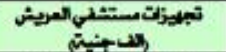 & T. \\
\hline ro... & ro... & . & . & . & . & ro... & 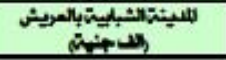 & $n$ \\
\hline ITVAA4 & & & & & & الإهمال & & \\
\hline
\end{tabular}

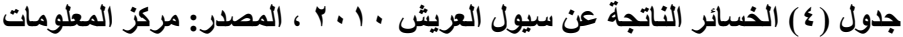

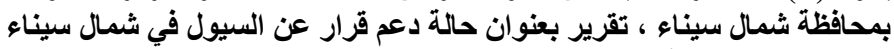

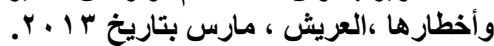

^- الايواء العاجل في شمال سيناء - مدينة العريش :

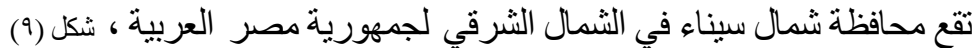

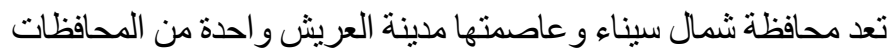

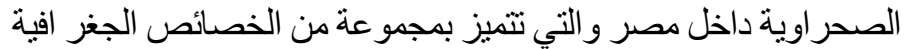
و الاقتصادية و الاجتماعية التي تجعل منها واحدة من المجتمعات المحلية شديدة

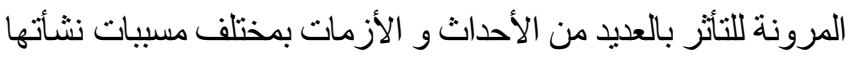

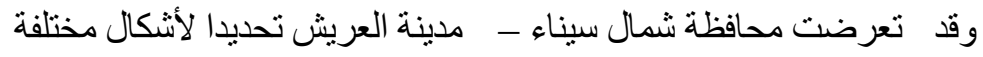
من الكو ارث ، سيتم در اسة حالات الايو اء العاجل في كارثة سيول العريش

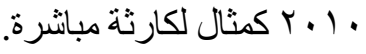

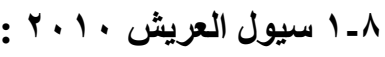
ضربت موجة من السيول مدن وسط سيناء

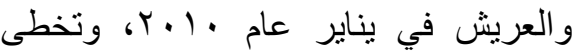

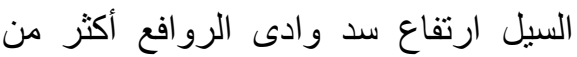
IVY المياه أعلى السد الذى يندفع بسرعة كبئ الئرة

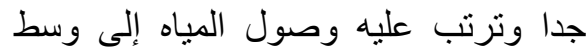
مدينة العريش ، حيث اندفع السيل بارتفاع ع

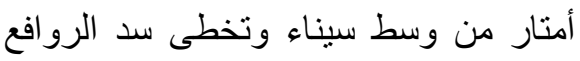

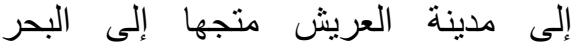

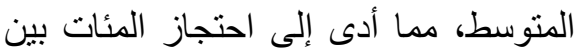

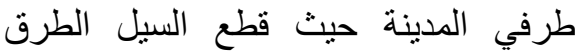
الدولية والداخلية نهائيا، فيما تم إغلاق مطار الدئ

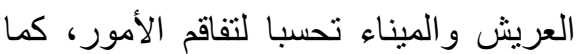
انقطع التيار الكهربائي لمدة تزيد عن ؛ ايام الام

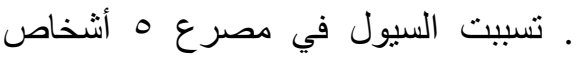
واختفاء شخصين و إصابة • ا، و وانهيار

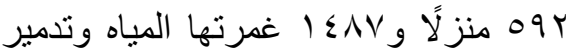

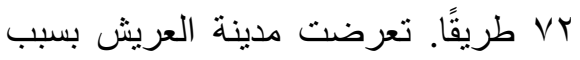
هذا السيل الى خسائر كبيرة مادية وطبيعية

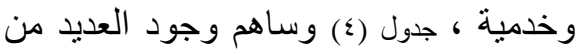
المعوقات على مجرى السيل في زيادة هذه ودئ الخسائر ،حيث انه يوجد على مجرى السيل

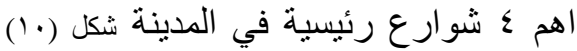

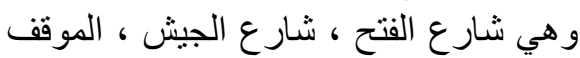

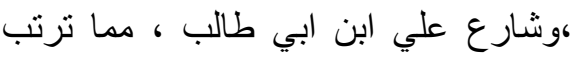

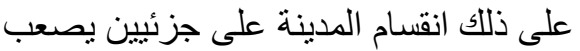

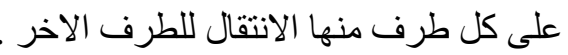




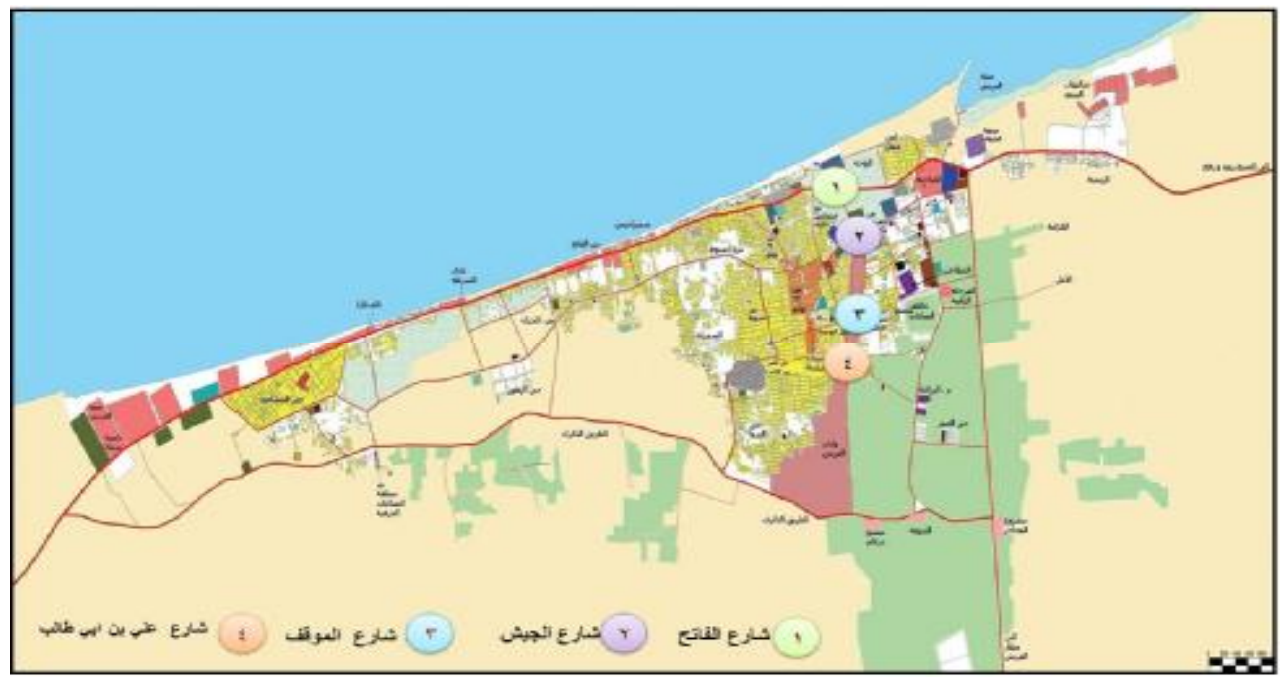

شكل ( • 1) الشوارع والميادين الرئيسية التي تأثرت بفعل السيل وادت الى انقسام المدينة. .

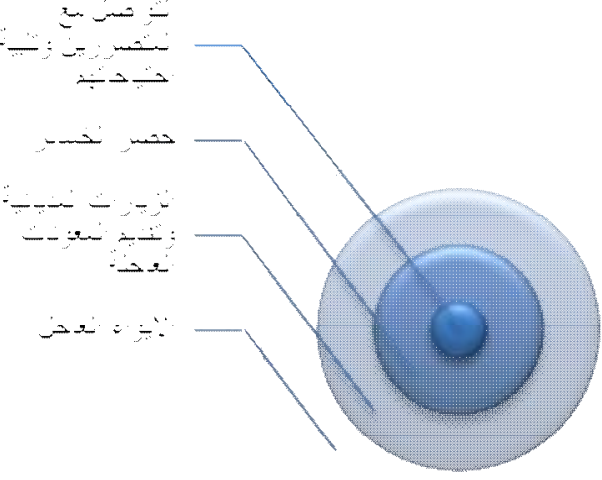

شكل (11 ) الاجراءات التي تم اتخاذها لإيواء المتضررين .

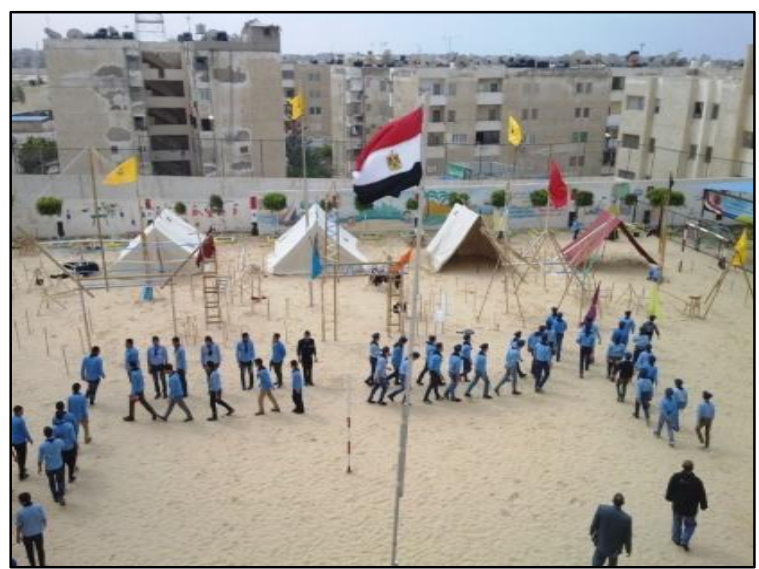

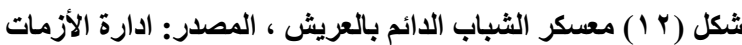

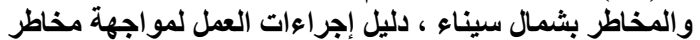

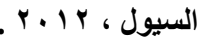

1ـ ـ ـ الإجراءات التي تم اتخاذها لإيواء المتضررين : شكل (11)

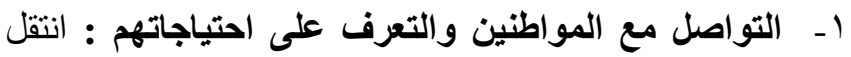

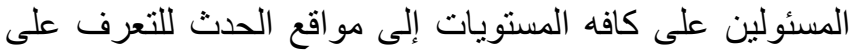
حجم الازمه و أثارها والاستماع لثكاوى المواطن اطنين و وتلبيه احتياجاتهم العاجلة . الاهم Y ـ حصر الخسائر : تم تشكيل لجان لحصر الخسائر بكافه أنو اعها (أهالي - حكومية) وقد أظهرت نتائج الحصر المبدئية أن

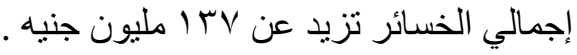

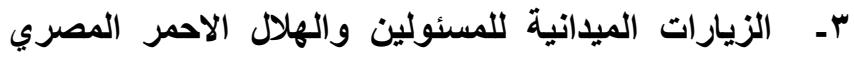
ومنظمات المجتمع المدني ورجال الأعمال لتوزيع المعونات

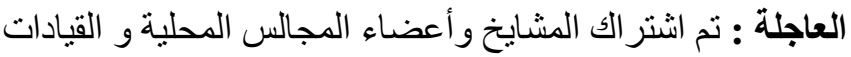
الطبيعية في التعرف على احتياجات المو اطنين العاجلة ،واستمرت منظمات المجتمع المدني والأجهزة الحكومية ورجال الأعمال

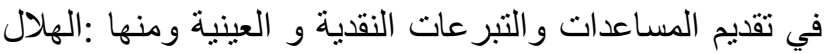
الأحمر المصري - مزي وزارة الإنتاج الحربي- ووزارة الدفاع -

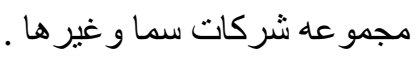

ع ـ الإيواء العاجل : فور حدوث الازمه تم فتح عمر مراكز للإيو اء منها معسكر الثباب الدائم في العريش ، وتم تقديم كافه وسائل الإقامة والإعاثة للمتضررين أثناء وبعد الازمه وفور وفئر استقرار الأوضاع عاد معظم المتضررين إلى أماكن إقامتهم أو أو

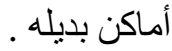

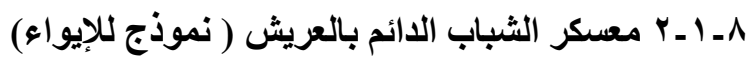
هنالك العديد من معسكر ات الثباب في شمال سيناء ولكن يعتبر

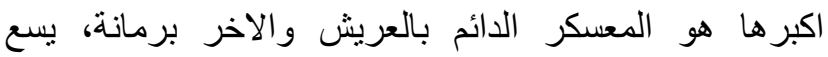

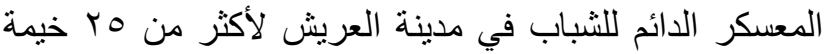
تستخدم في الحالات العاجلة والمخيمات الصيفية كينم نصبها وتجهيزها في حالة الكوارث في مدة زمنية لا تتعدى اليوم

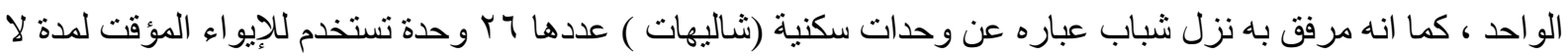
تتعدى السنة ـ شكل (I)

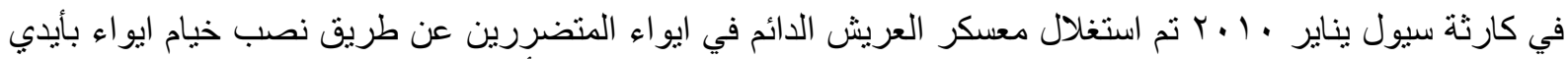
متطوعين مدربين على ذلك ، و يتم اتخاذ الاجراءات اللازمة للتنفيذ من قبل الأجهزة المعنية ( مجلس مدينة العريش - 


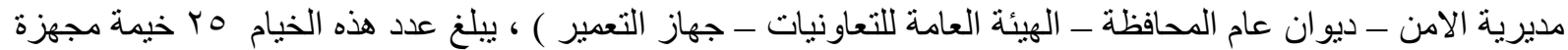

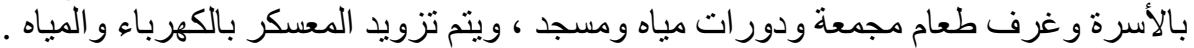

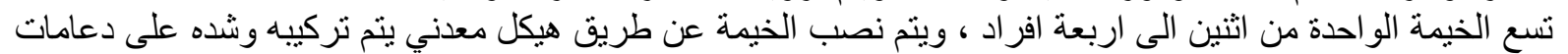

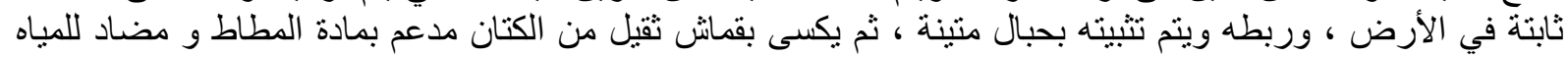

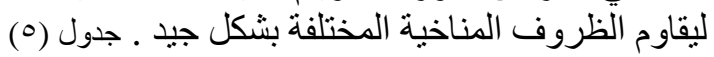

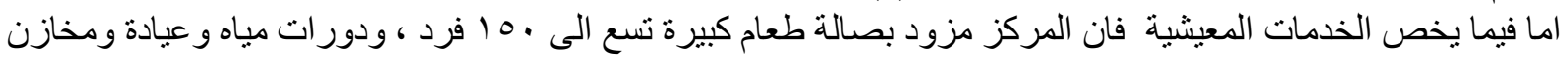

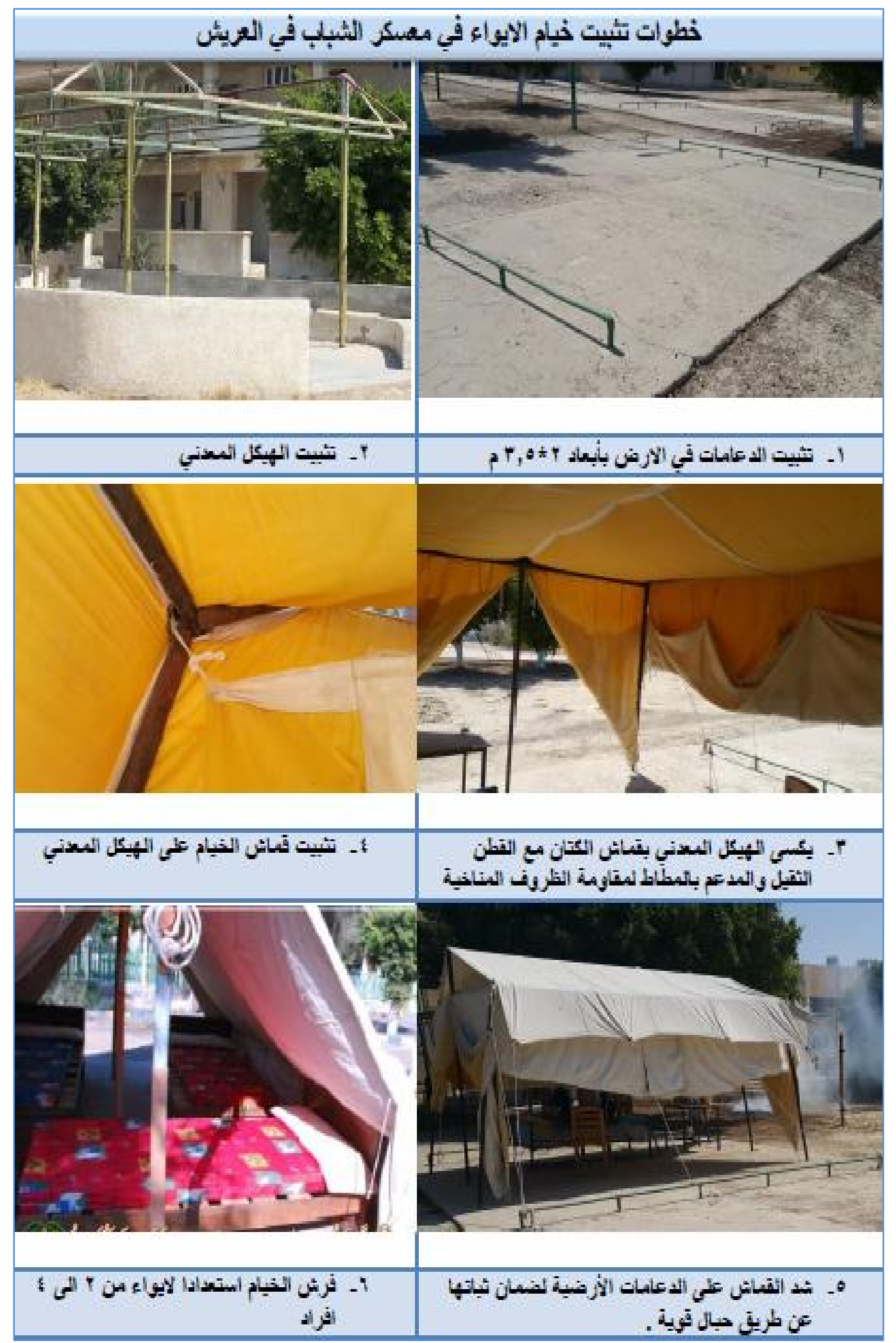

جدول (ه) خطو ات تثبيت خيام الايو.اء في، معسكر. الثباب فه، العر يش. 
و واماكن مفتوحة . شكل (rا ) ، شكل (ع () )

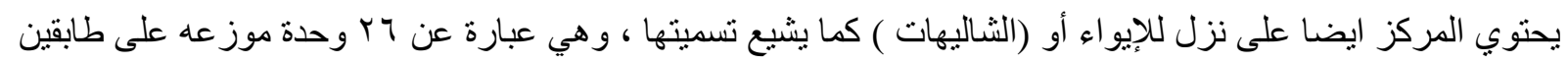

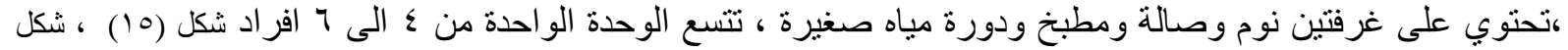

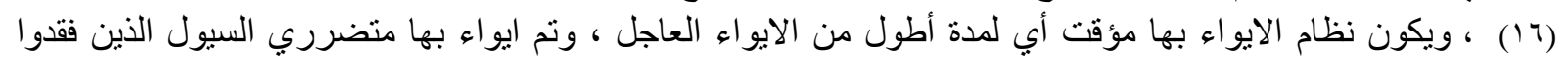

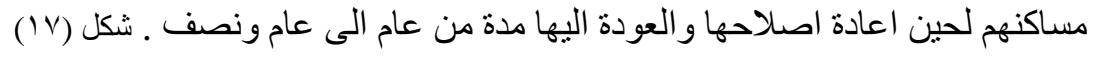

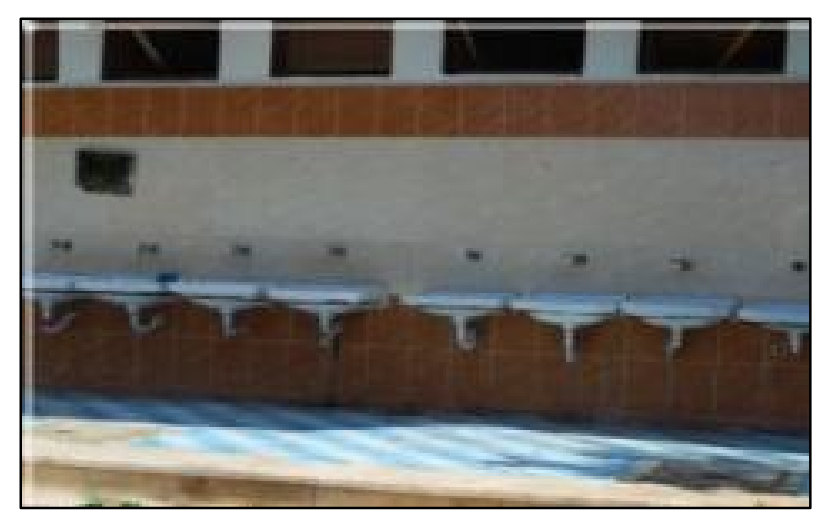

شكل (ع ا ) مغاسل منطقة المخيمات في معسكر الثباب بالعريش

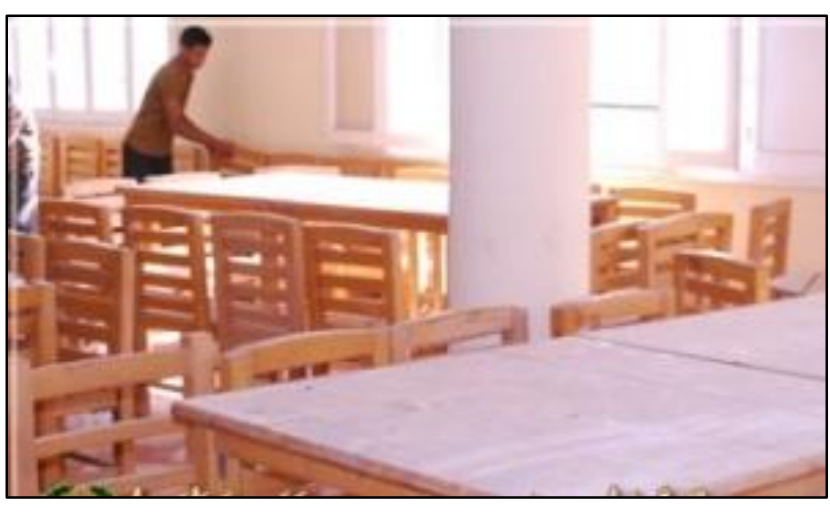

شكل (ب ا ) صلة الطعام المرفقة بمعكر الثباب بالعريش.

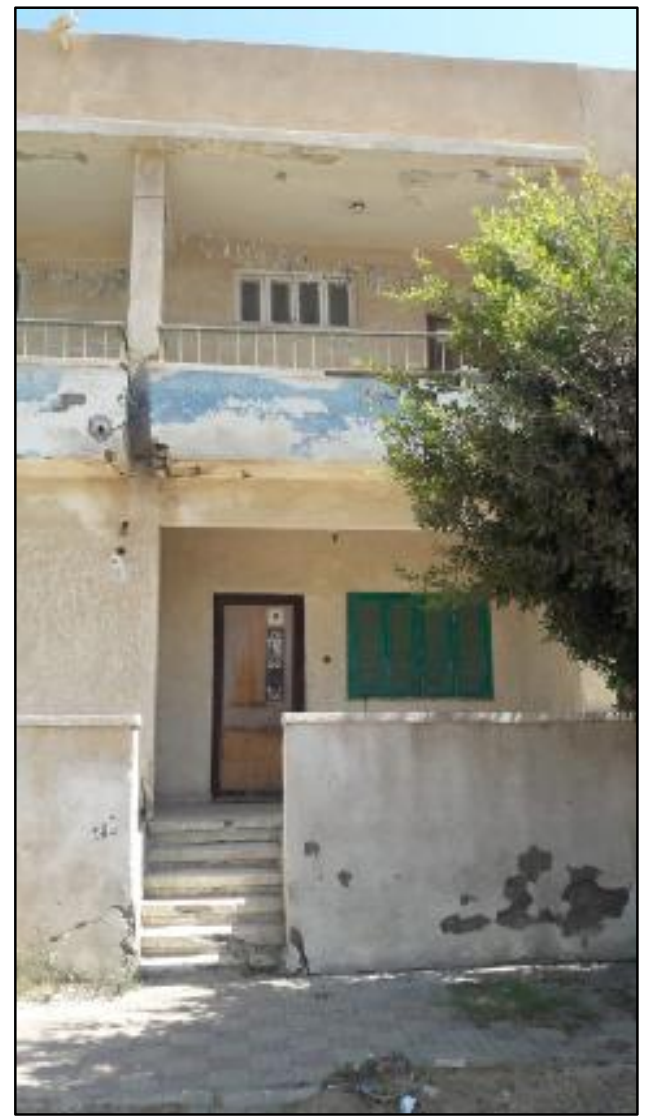

شكل (17 ا ) صورة لأحد الوحدات .

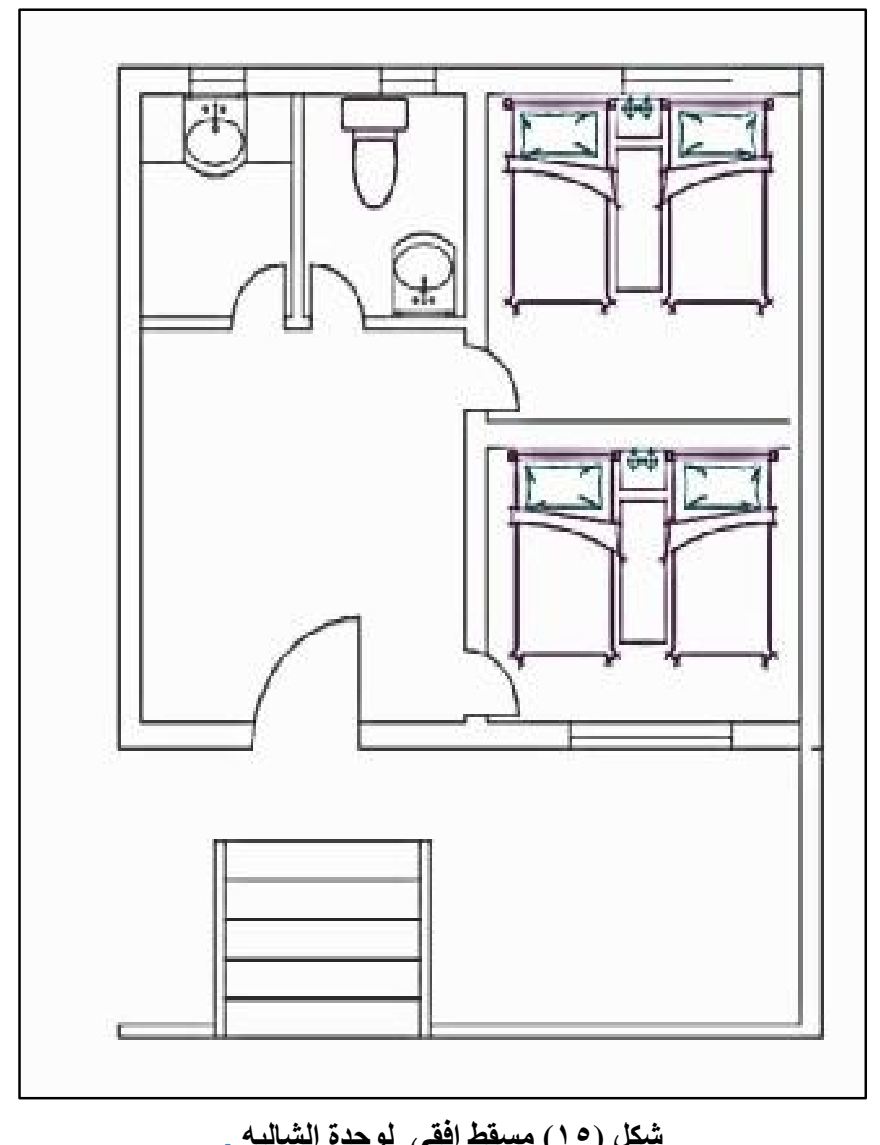

شكل (0 10) مسقط افقي لوحدة الثاليه . 
منطقة مخيمات الايو اء تحتوي 0r خيمة وتستخدم بشكل عاجل خلال مدة لا تتعدى الثهرين $\downarrow$

筩

(6)
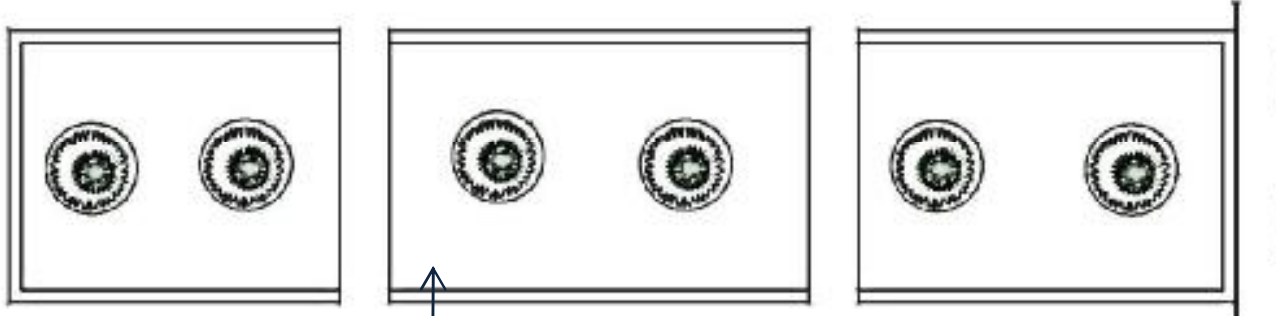

(a)

(2)

مدخل المخيمات

(2)

36

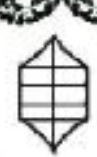

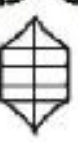

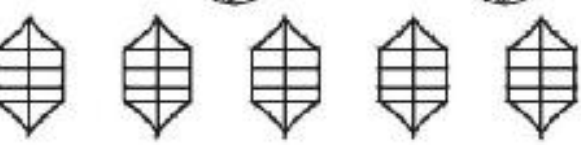

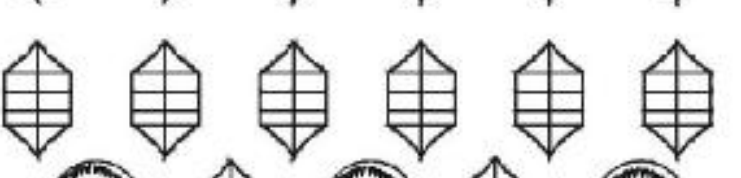

(9) 1 (0) 10

(1)

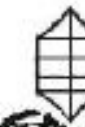

$\checkmark$

1

些

and

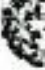

مناطق استر احات وجلوس

سور شجري للمحافظة على خصوصية المخيمات

شكل (V) ) مسقط افقي الدور الارضي لمركز الثباب الائم والذي تم استخدامه في ايواء متضررين سيل ـ 1 ب بالعريش . 
يعتبر معسكر الثباب الدائم من افضل اساليب الايو اء العاجل الموجودة في العريش بسبب موقعه المميز واستعداده

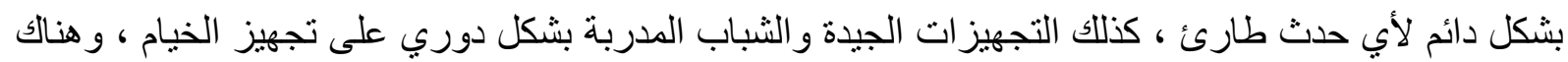

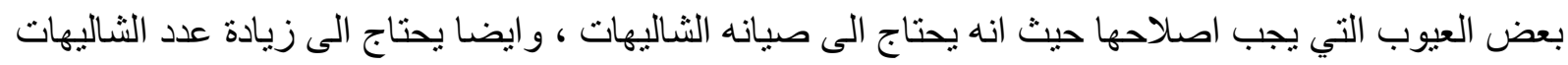
ومساحة المخيمات حتى يحتوي عدد أكبر من المتضررين، ويوضح جدول (آ) تقييم المعسكر كمركز للإيواء العاجل.

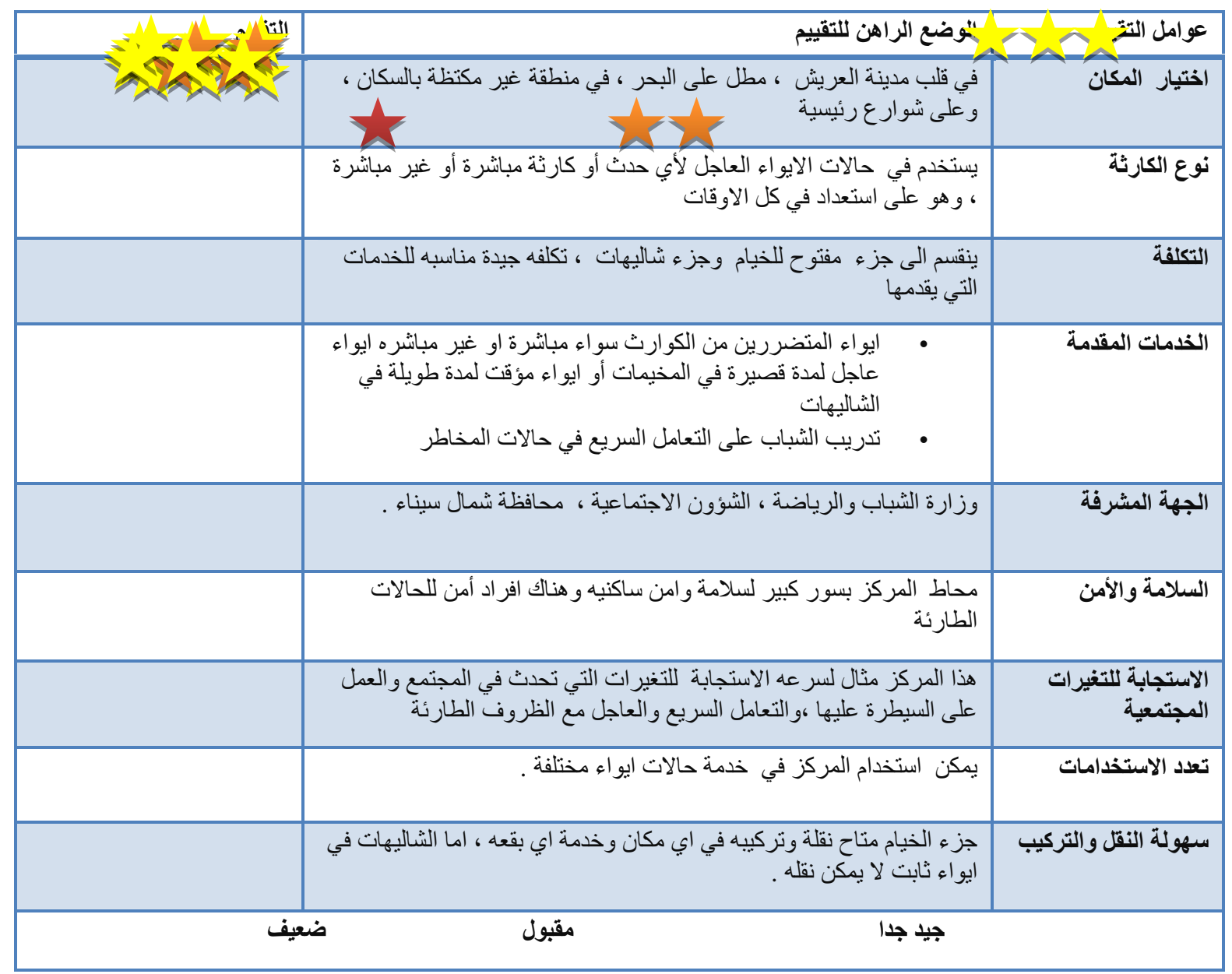

جدول (†) تحليل وتقييم مركز الثباب الائم بالعريش .

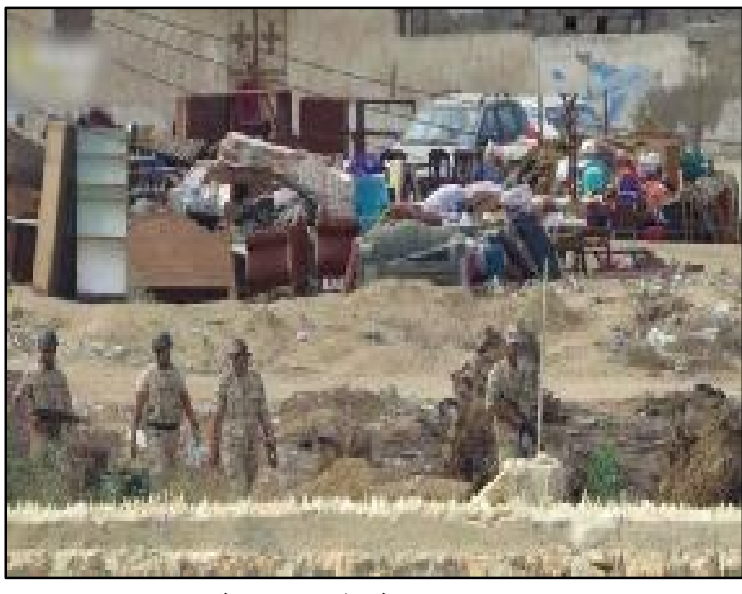

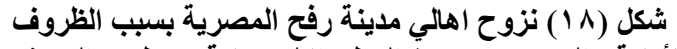

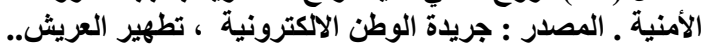

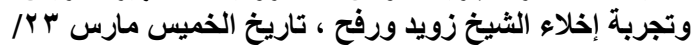

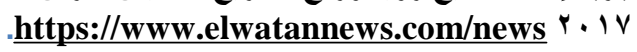

\section{: نزوح سكان مدينتي رفح والثيخ زويد r.A} النزوح هو نرك الثخص منطقته ليستقر في مكان آخر ، وهو

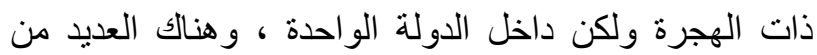

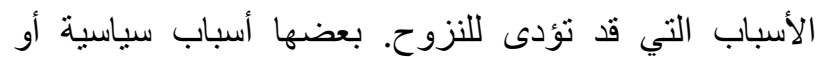
اقتصادية، أو لأسباب شخصية ، تعتبر حركة النّاب النزوح خاصة

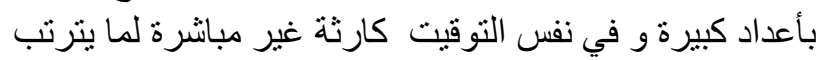

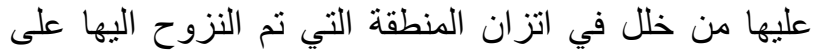

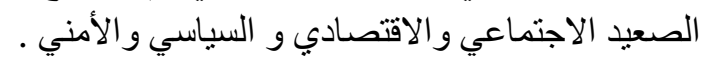

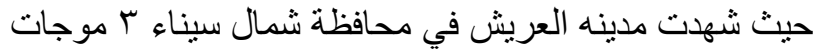

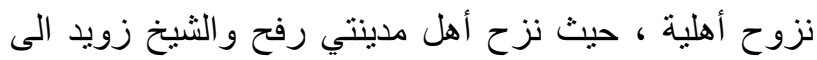

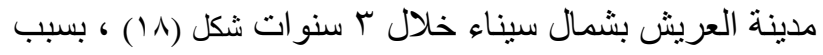

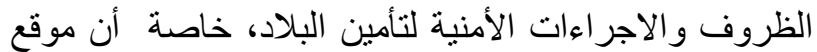

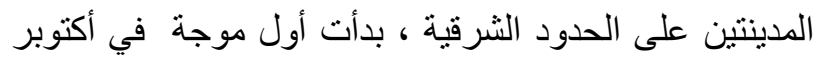

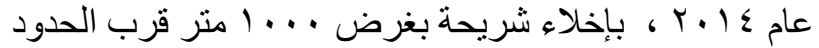


المصرية الفلسطينية في رفح ،بهدف إنشاء منطقة أمنية عازلة لحماية الحدود، وتم ترحيل الأهالي على مرحلتين شملت

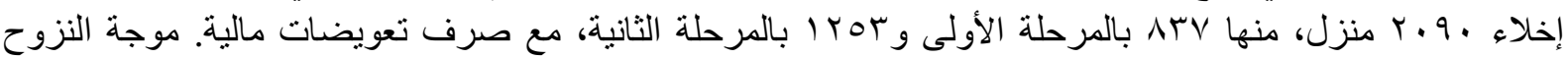

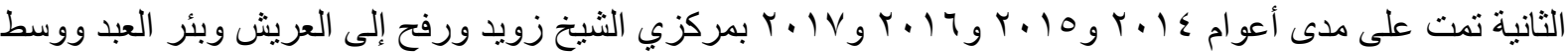

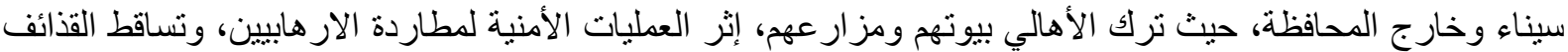

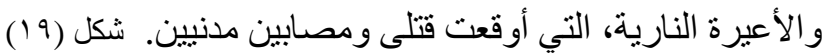

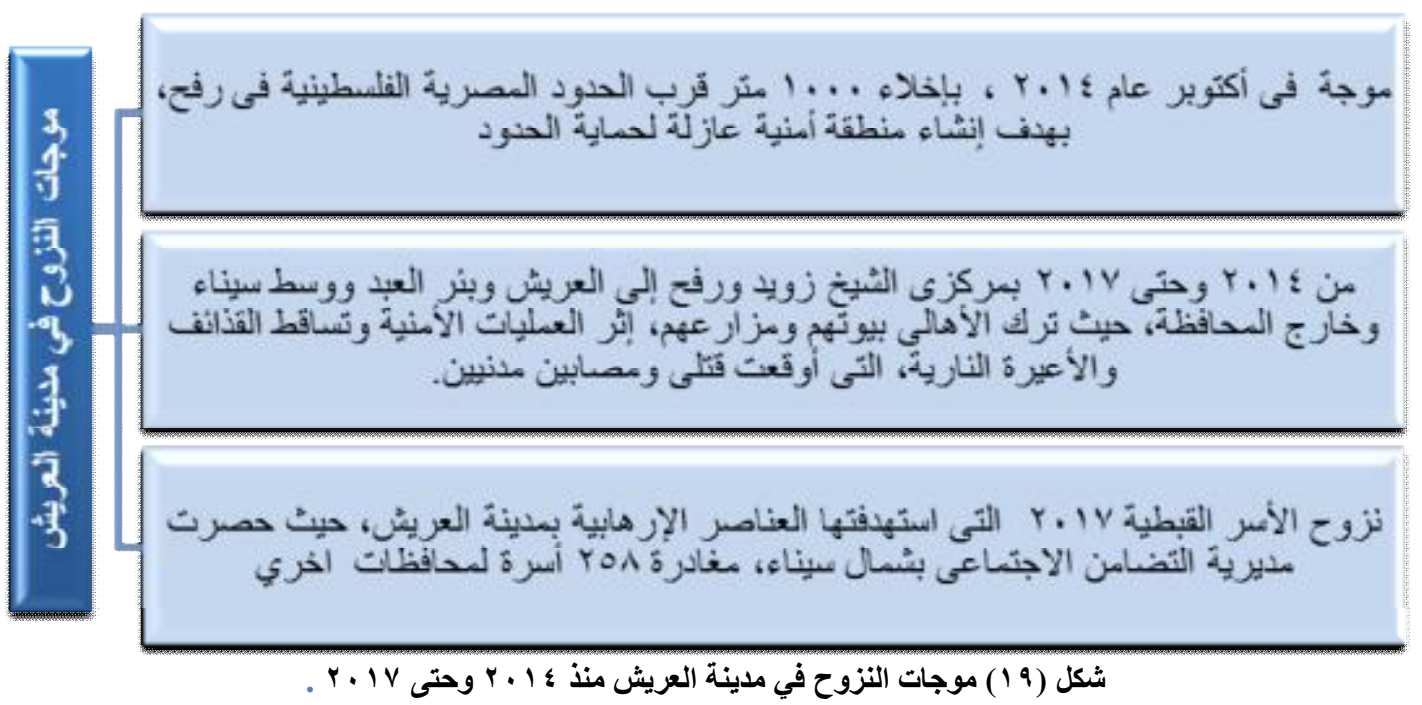

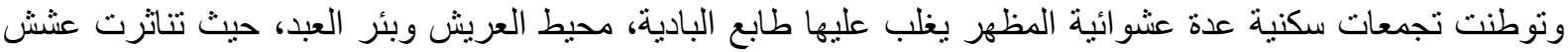

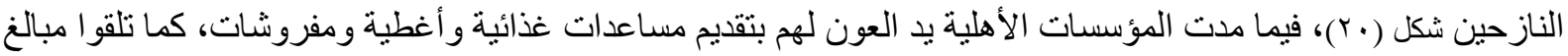
مالية ومستلزمات بناء عشش ومفروشات و أجهزة، من لجنة رسمية مشكلة من ديو ان عان عام المحافظة.

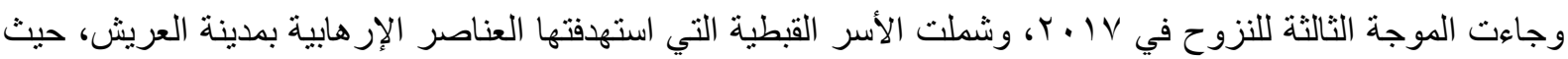

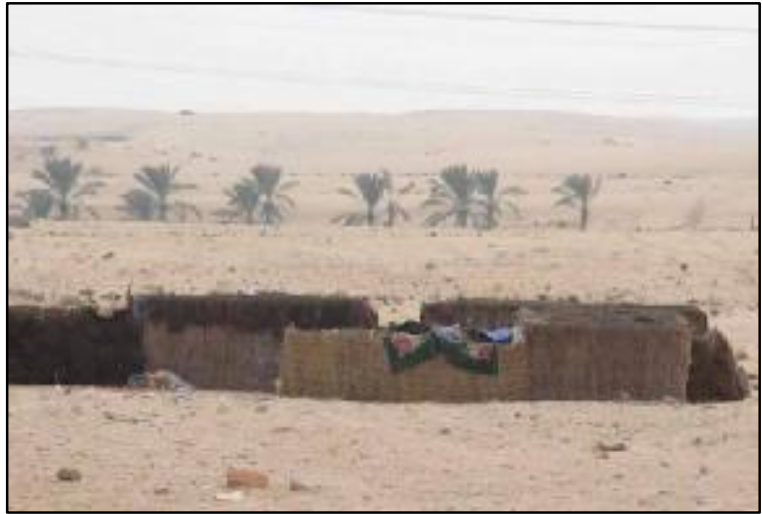

شكل · r عشش النازحين في الاماكن الخالية من مدينة العريش. حصرت مديرية التضامن الاجتماعي بشمال سيناء، مغادرة

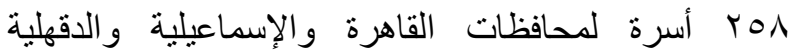

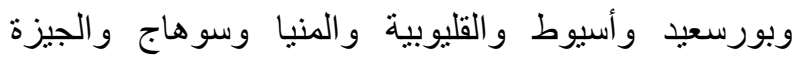
و الفيوم و الثرقية و الغربية وبنى سويف.

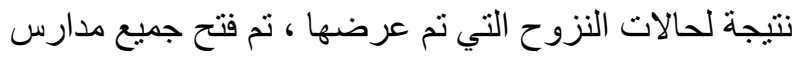

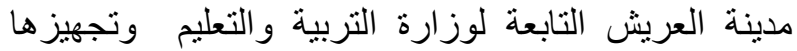

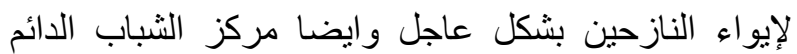

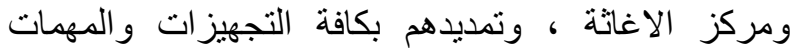
الازمة لإيواء النازحين ، لحين توفير مساكن بكانة دائمة لهم وصرف التعويضات المناسبة .

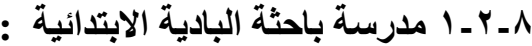

تعتبر مدرسة ( باحثة البادية الابتدائية ) من أثشر المدارس الابه

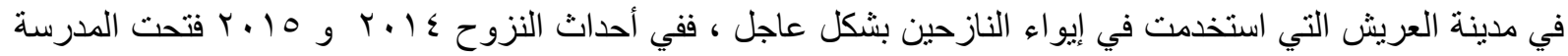
ابو ابها لإيواء النازحين لحين توفير مساكن مؤقتة لهم ، وكانت المدرسة مزودة بكافة الاحتياجات المعيشية من أسِرة و و أغطية (بطاطين ) ، وتزويدها بالأغذية و المستلزمات المعيشية اللازمة ، و تتكون مدرسة الباحثة من بـ بـ فصل يستطيع كل

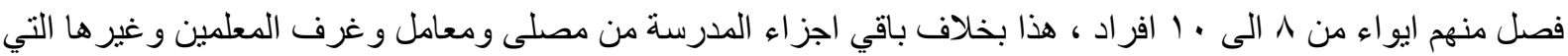

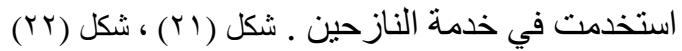




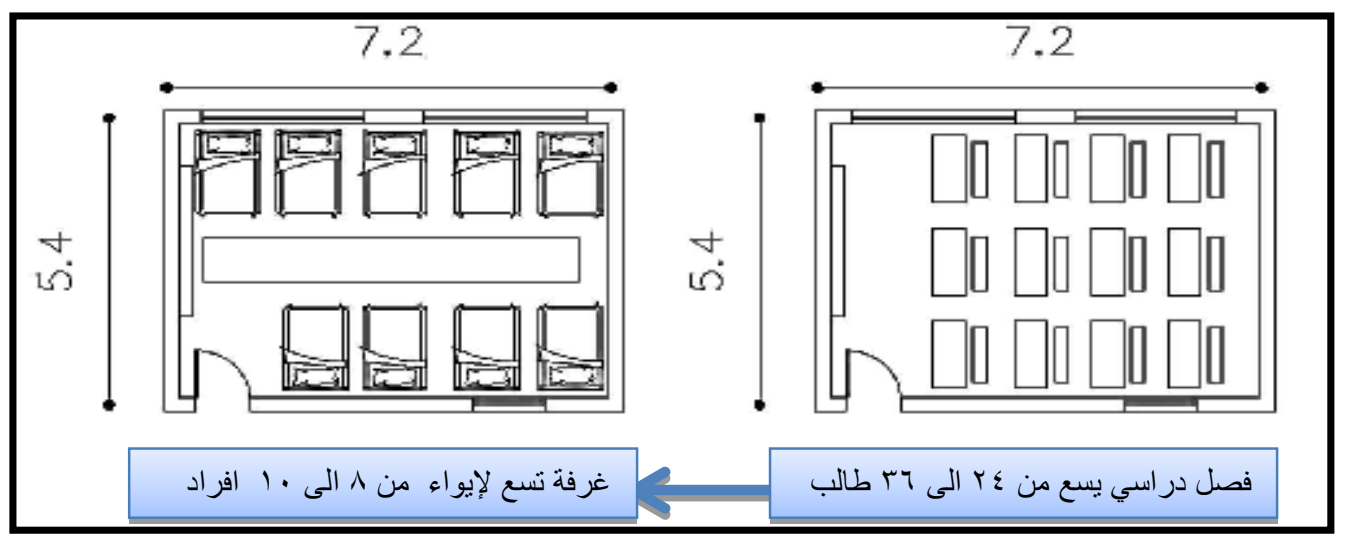

شكل ( آT) تحول الفصل الى غرف نوم في مدرسة باحثة البادية .

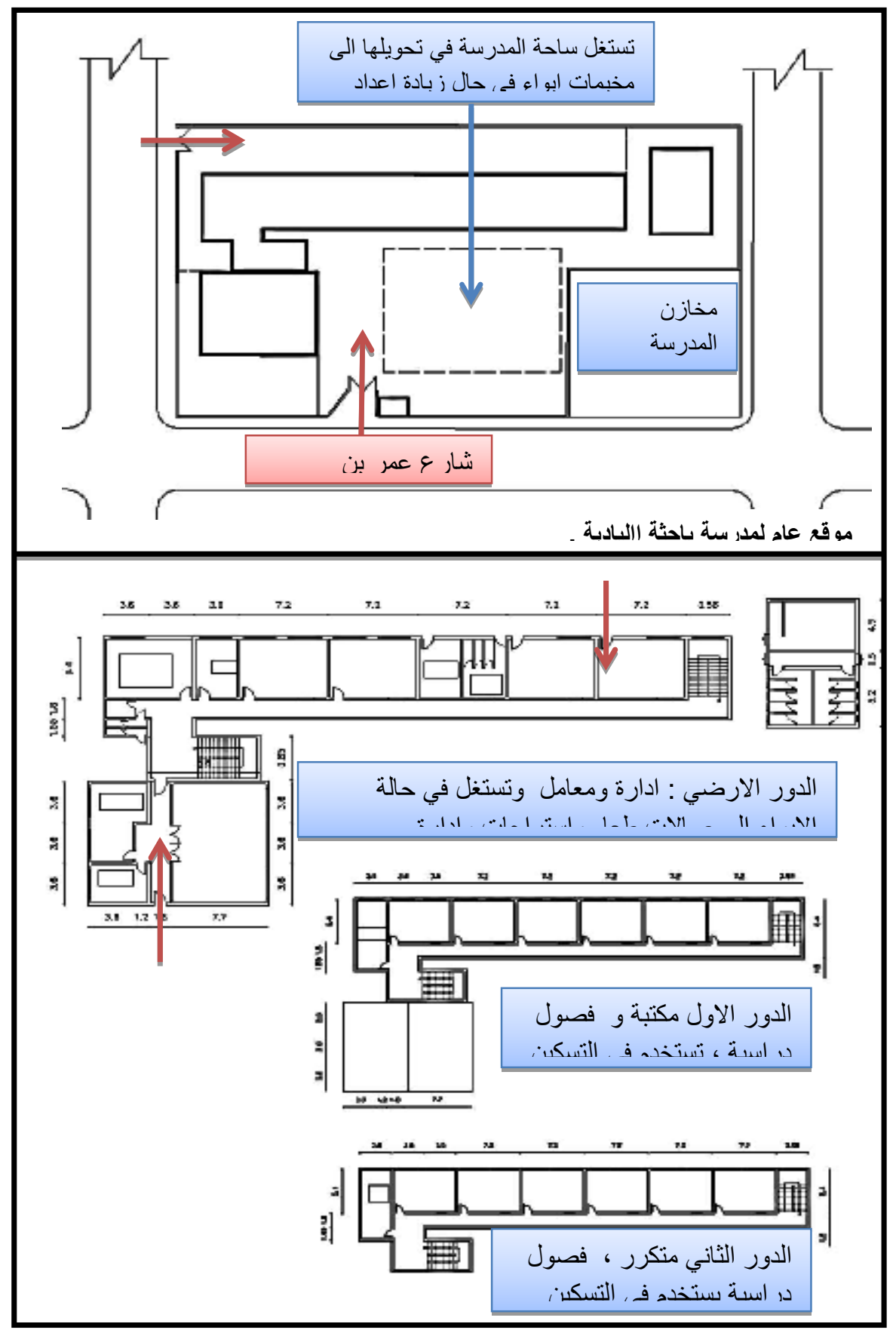

شكل (rr ) استغلال عناصر مدرسة باحثة البادية في الايواء العاجل . 
يعتبر استغلال المدارس في مدينة العريش كماوى عاجل في حالات الكوارث ، الية جيدة وفعالة ، تتميز بسرعة الاستجابة

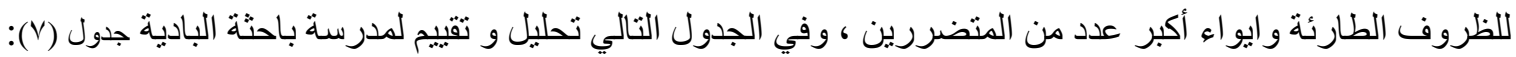

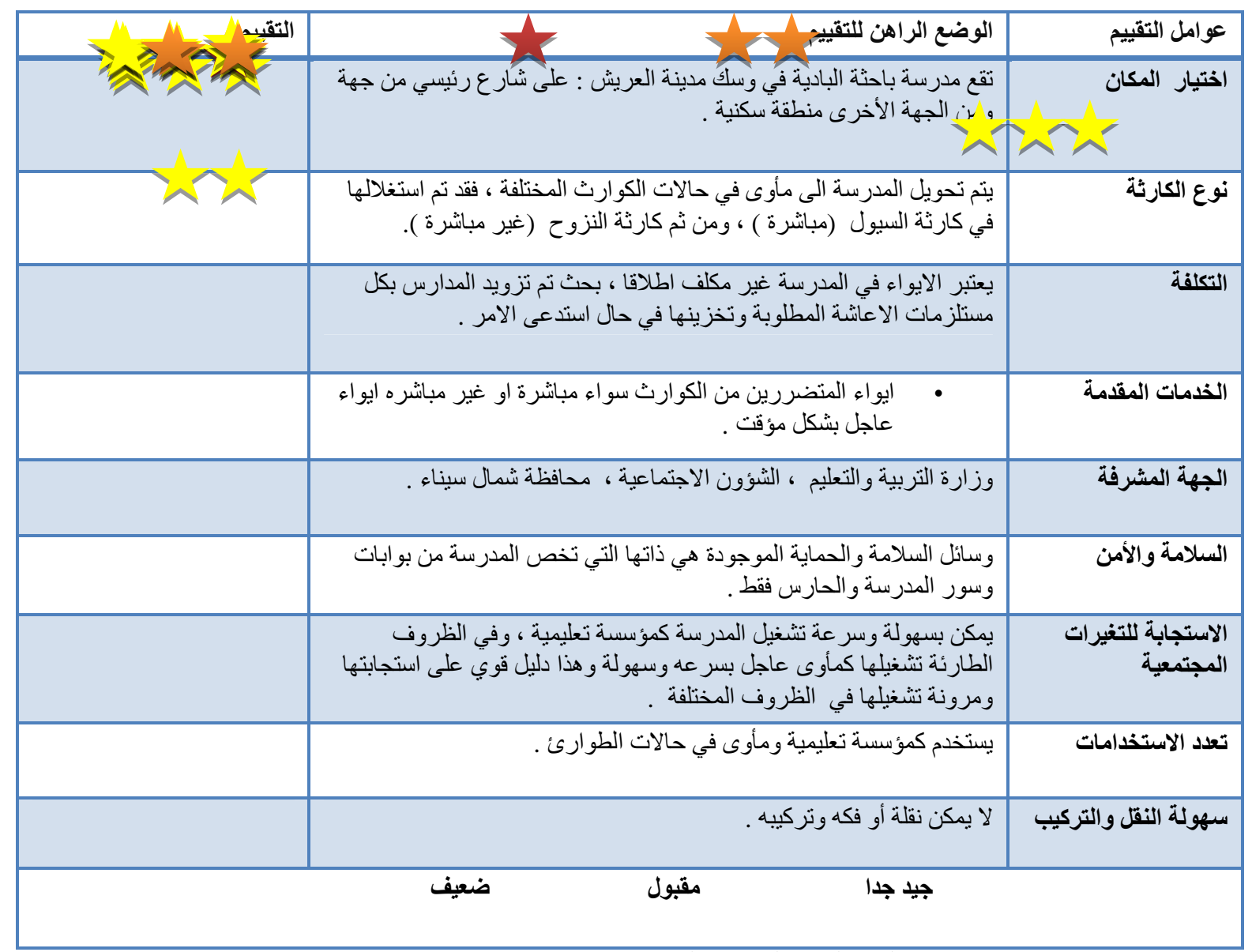

جدول (V) تقييم مدرسة باحثة البادية في مدينة العريش كمثال على استغلال المدارس في الايواء العاجل .

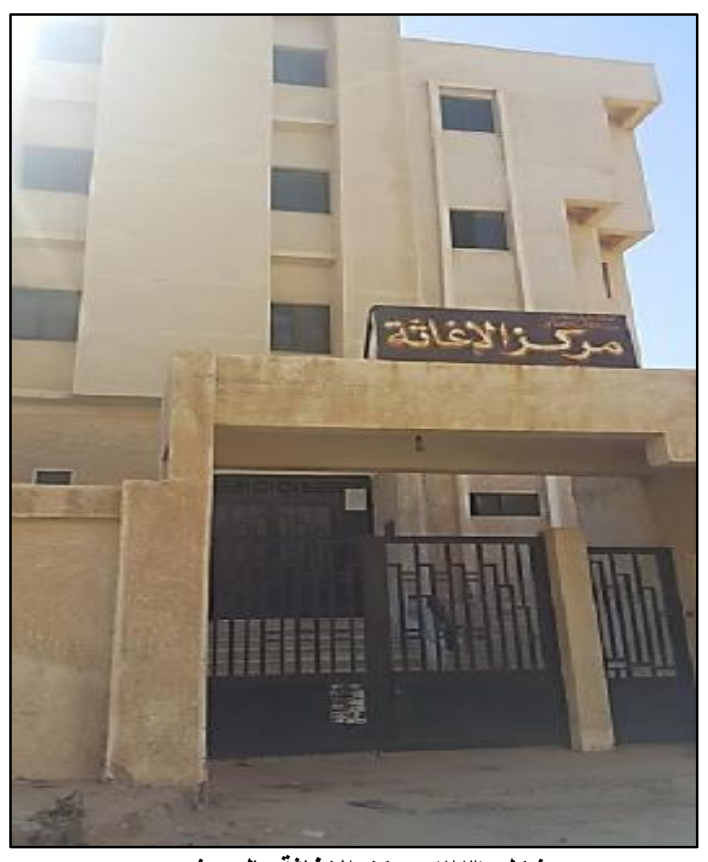

شكل (r T) مركز الاغاثة بالعريش .

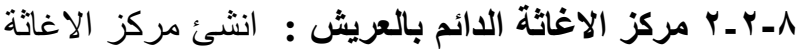

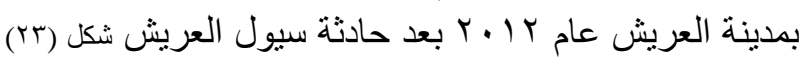

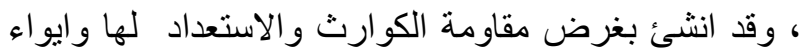

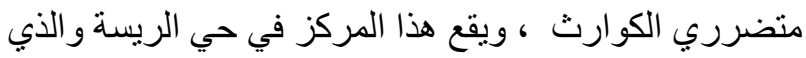

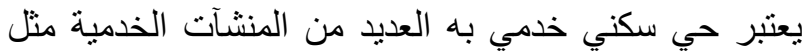

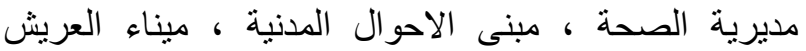

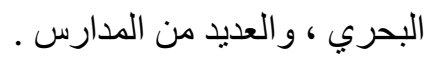

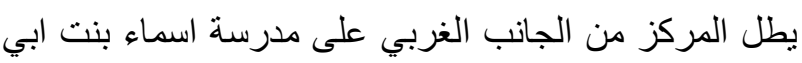

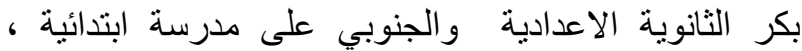

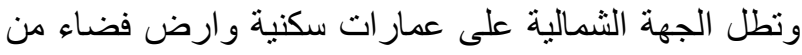

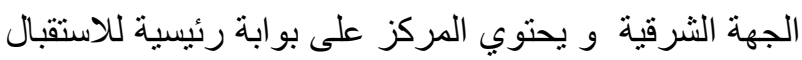

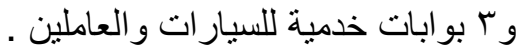

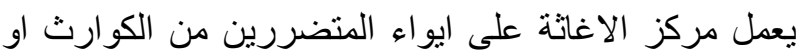

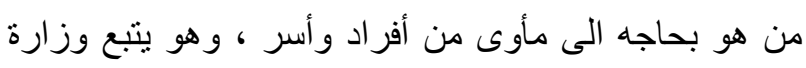


التضامن الاجتماعي ، وقد تم اشغال هذا المركز بالكامل في أحداث نزوح أهل رفح والثيخ زويد لحين انتقالهم الى مسكن

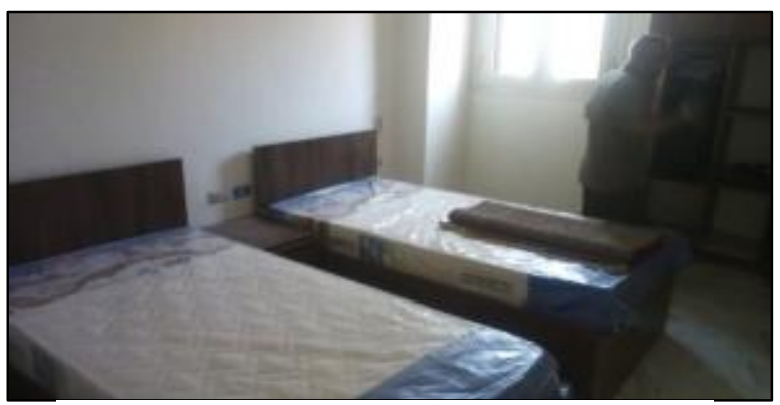

شكل (؟ ץ) غرف النوم كم الداخل .

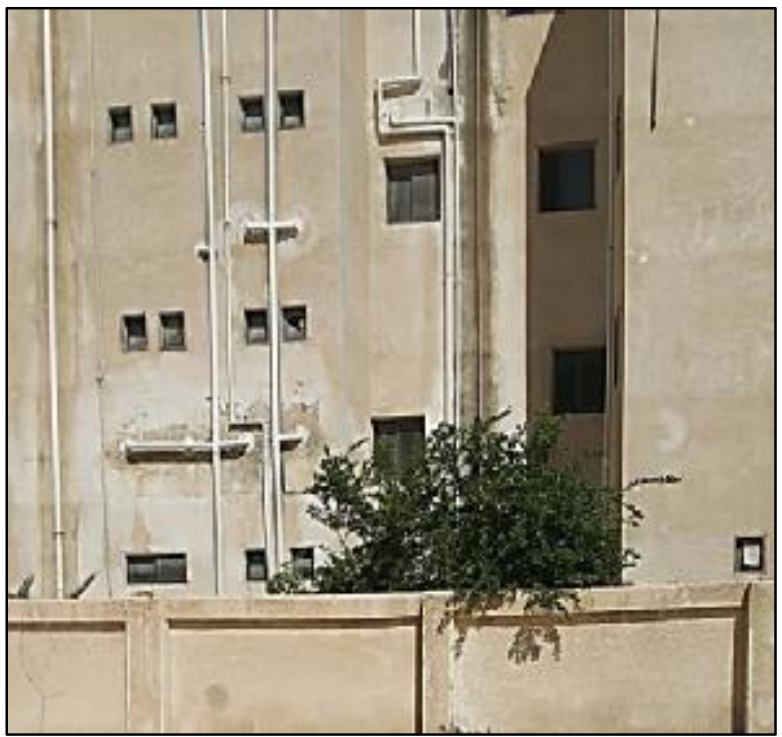

شكل (0) صورة توضح احتياج المبنى لصياتة اعمال السباكة .

قام المركز بنوفير اقامة مؤقتة للأسر والأفراد من النازحين

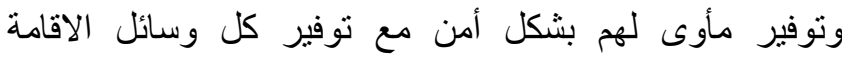
المريحة و الحماية عن طريق :

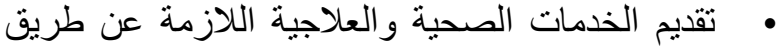
عيادة دائمة بالمركز وزيار ات طبية دورية . • تقديم الخدمات القانونية اللازمة عن طادية دريق دورية فريق محاميين مختصين بالحالات المشابهة وتقديم الاور اق تلقية

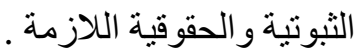
• تقديم خدمات التعليمية والمدرسية اللازمة لأطفال النازحين و الاهتمام بحقهم في التعليم . • العمل على توفير مسكن دائم لهم بالتتسيق مع المحافظة يتكون المركز من ع طوابق ، الدور الأرضي لاستقبال النزلاء

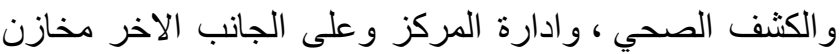

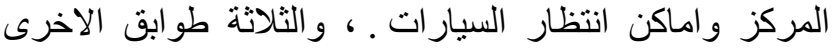

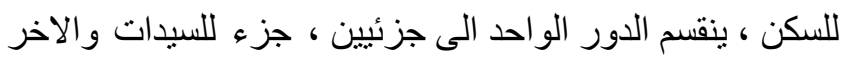

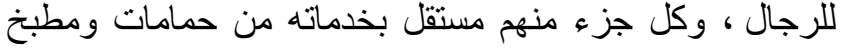

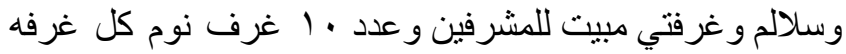

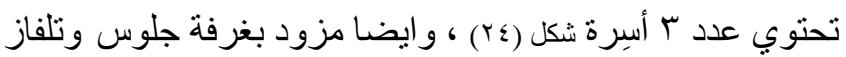
في كل قسم. . حالة المبنى جيدة ، يحتاج لصيانة لأعمال السباكة

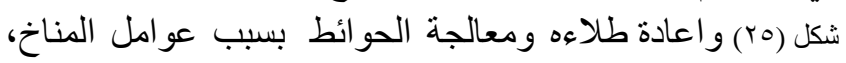

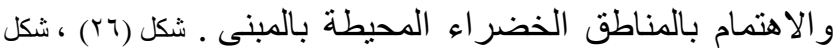

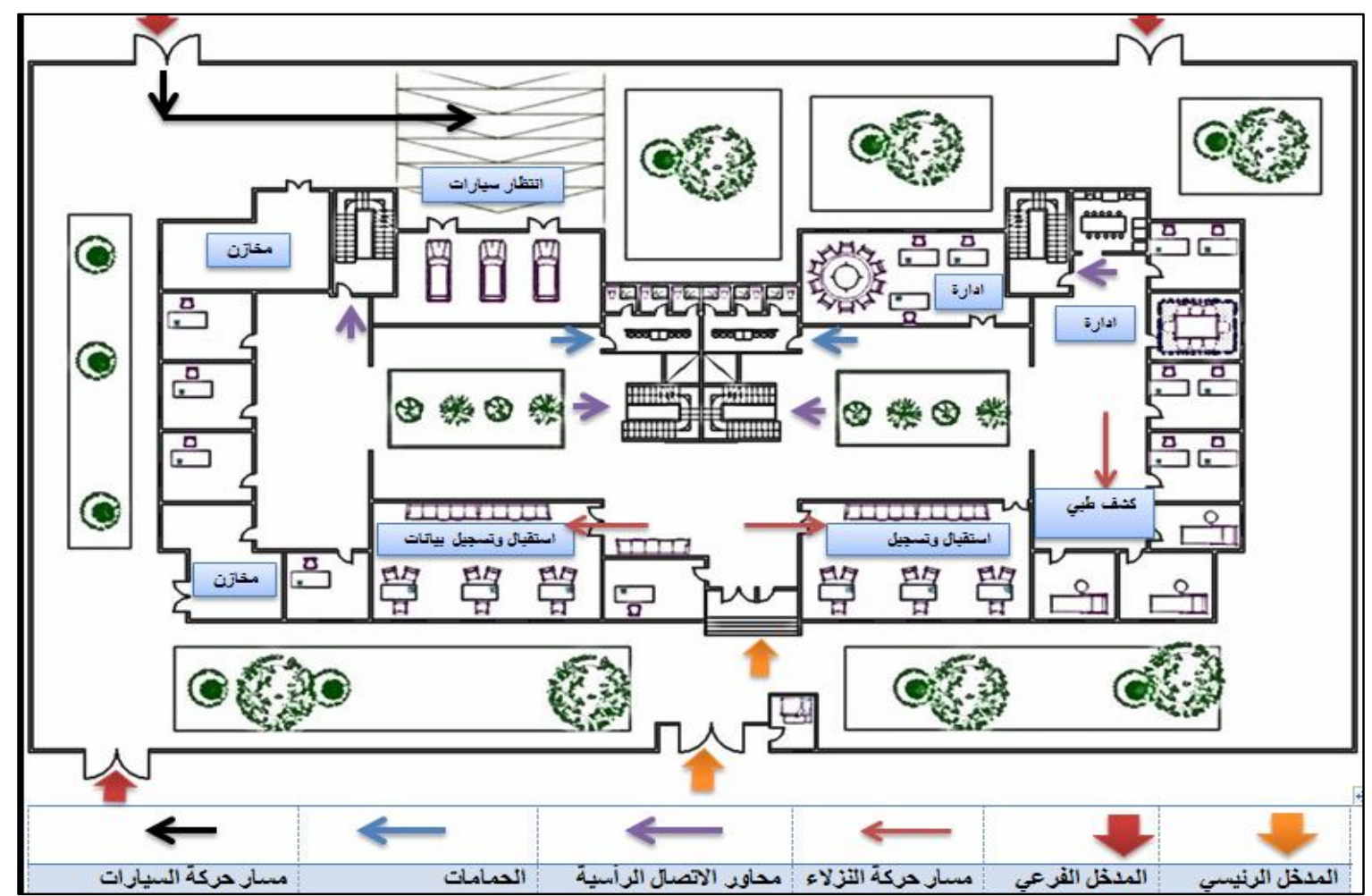

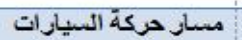
شكل (Y Y T) المسقط الاققي لمركز الاغاثة بمدينة العريش . 


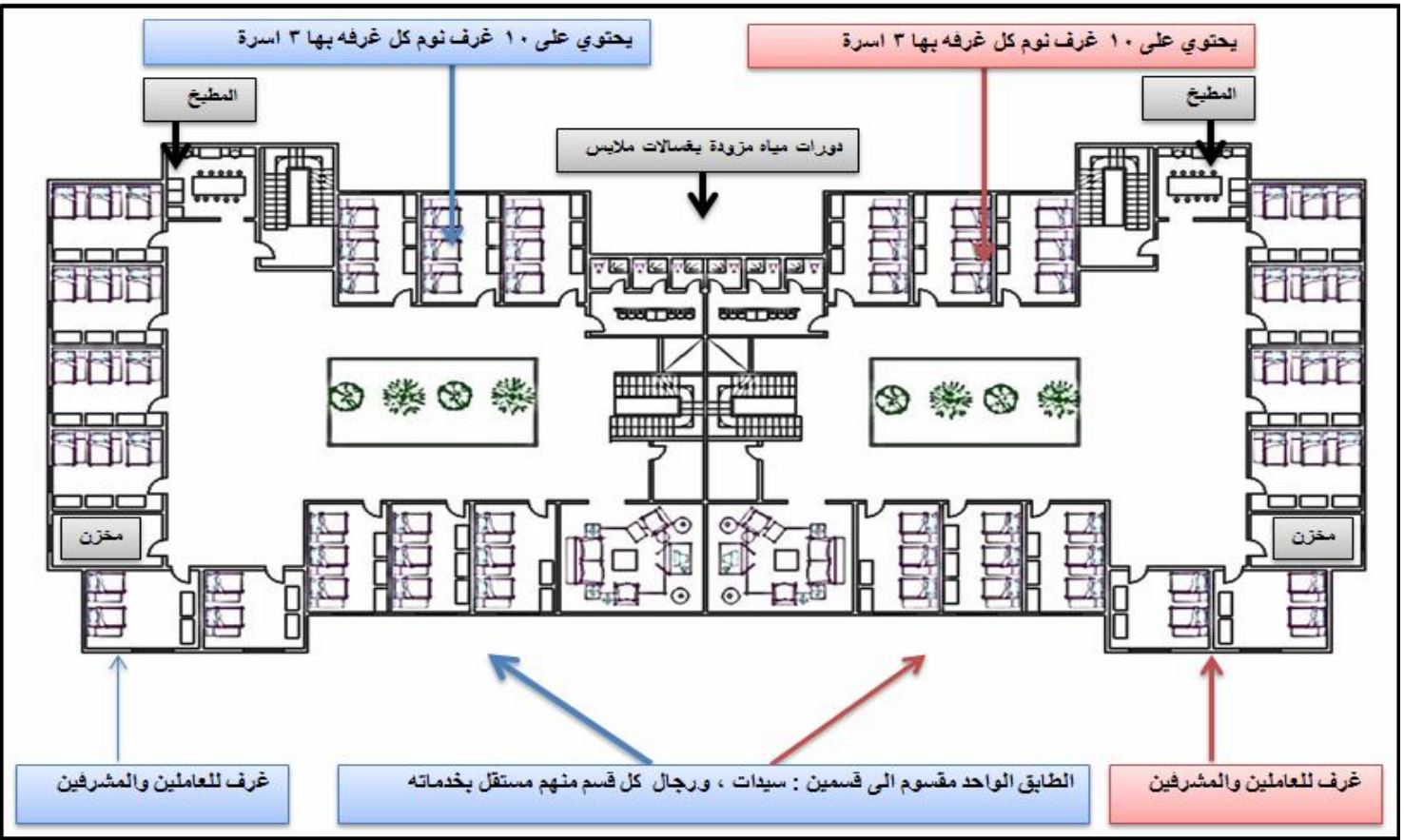

شكل (YV) يوضح المسقط الافقي للأدوار المتكررة .

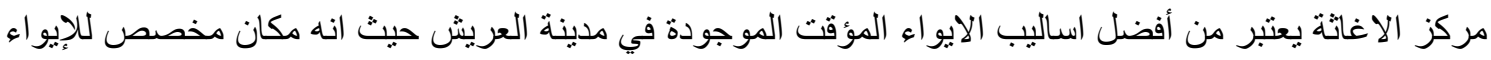

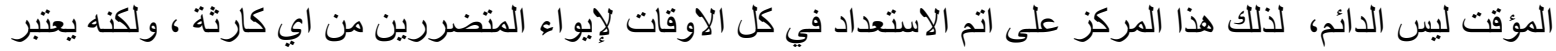

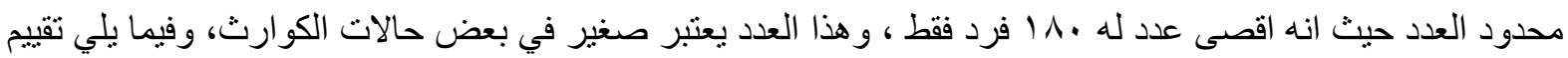
لالمركز : جدول (^)

جدول (^) تحليل مركز الاغاثة في مدينة العريش لإيواء المتضررين والنازحين .

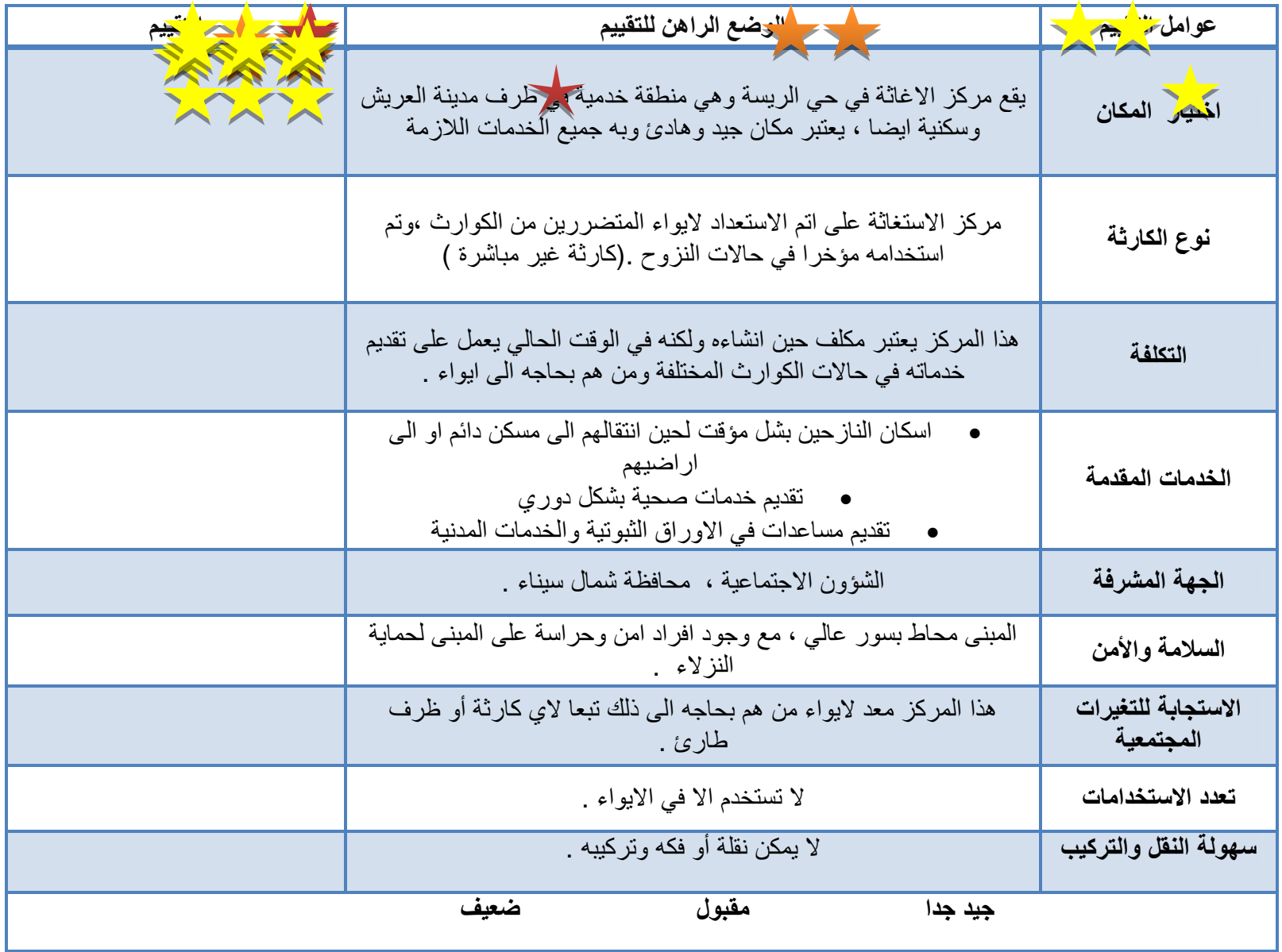


ــ مقارنة بين كيفية تطبيق الايواء العاجل في التعامل بين كارثثي سيول العريش ونزوح سكان مدينتي رفح والثيخ زويد

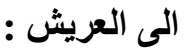

يقارن الجدول التالي بين اليات الايو اء المستخدمة عند حدوث كارثثين مختلفتين ، فبعد در اسة الكوارث التي التي اصابت مدينة

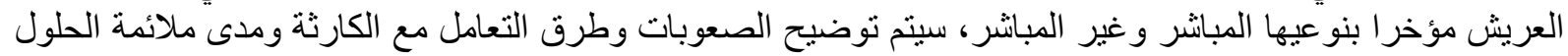
جدول (9) مقارنة بين كارثتي السيول والنزوح التي اصابة مدينة العريش

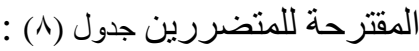

\begin{tabular}{|c|c|c|}
\hline ونزوح سكان مدينتي رفح والثيخ زويد & سيول العريش & اوجه المقارنة \\
\hline كارثة غير مباشرة (مجتمعية ) & كارثة مباشرة & طبيعة الكارثة \\
\hline مدينة العريش ـ مدينتي رفح و الثيخ زويد مدنهم واستقر ارهم في & سليول الصايتر وقسمت المدينة شمال سيناء قسمين أدت الي العديد من & تعريف الكارثة \\
\hline 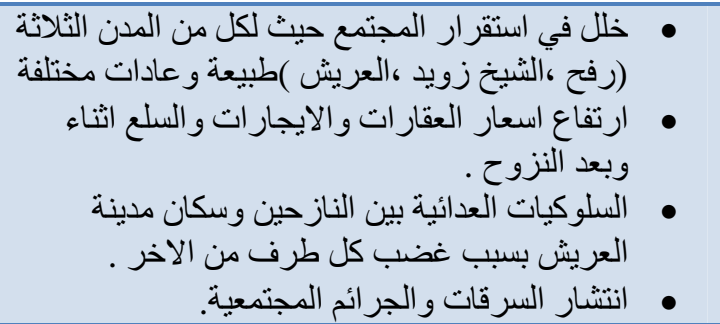 & 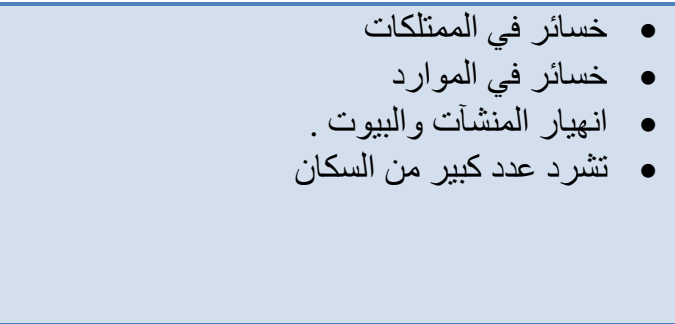 & نتائج الكارثة \\
\hline 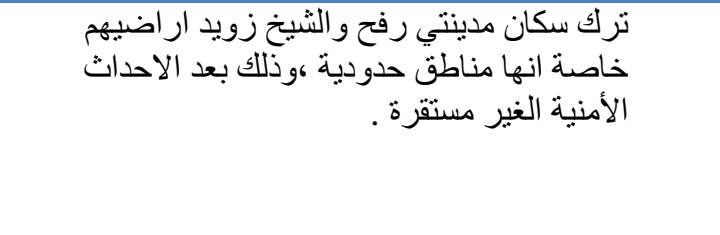 & 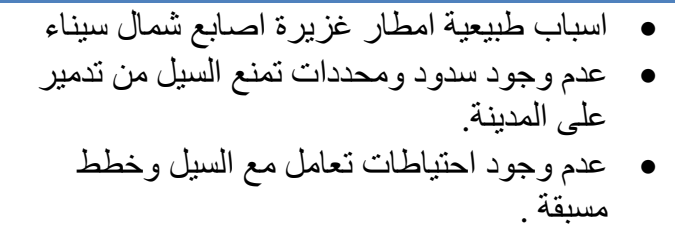 & أسباب الكارثة \\
\hline 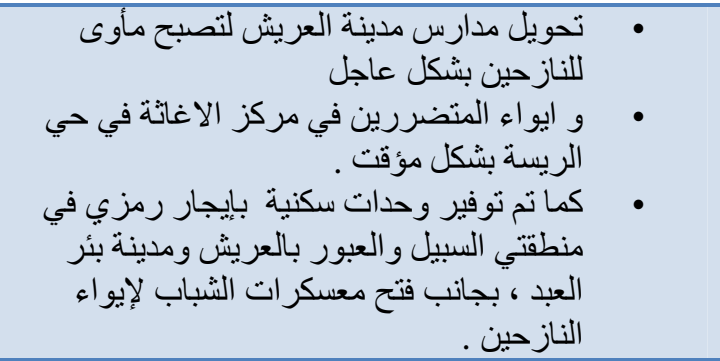 & 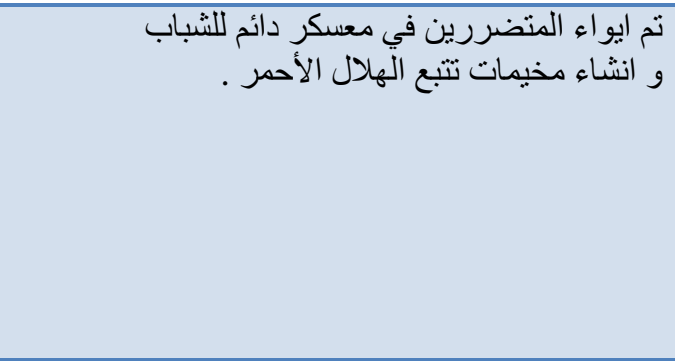 & $\begin{aligned} \text { الايواء العاجل } \\
\text { العارثة }\end{aligned}$ \\
\hline 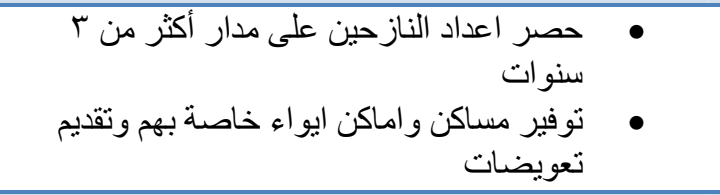 & 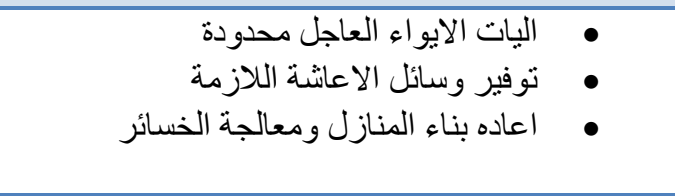 & 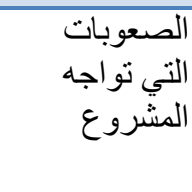 \\
\hline تقديش وحدات سكنية في مناطق مختلفة من مدينة & تم بناء مركز الكارثنة وبناء سذود تعمل على حجز السيول & الت التطورات \\
\hline
\end{tabular}

يجب التأكيد على ضرورة تحديث البيانات الخاصة بإدارات الأزمات والكوارث على مستوى محافظة شمال سيناء ،

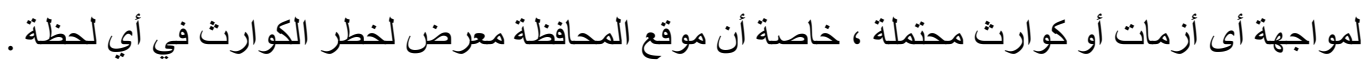

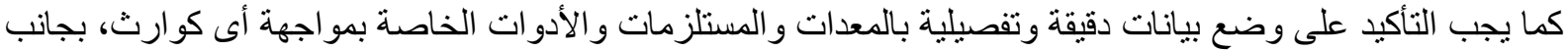

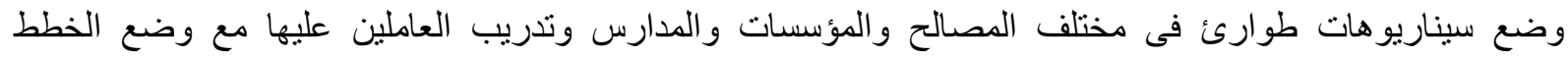
والاستراتيجيات واليات ايواء عاجل ومؤقت مختلفة لمواجهة الكوارث سواء كوارث مباشرة أو غير مباثرة نتيجة ظروف طارئة قد تتعرض لها المحافظة . لهات 


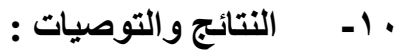
اولا - النتائج : النيان

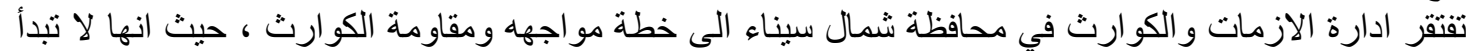

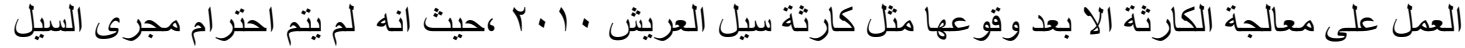

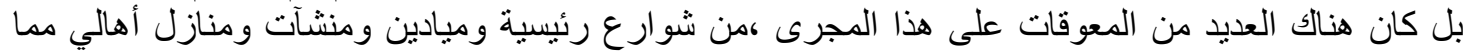

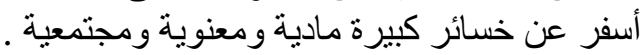

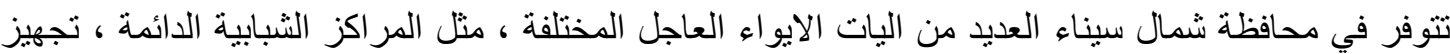

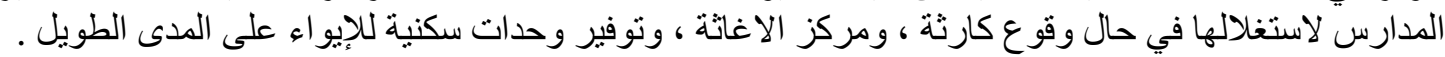

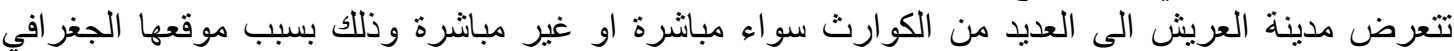

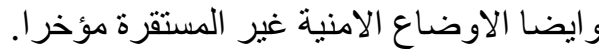

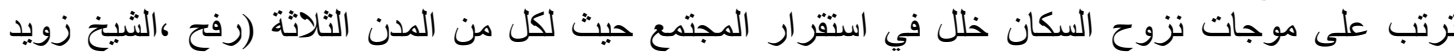

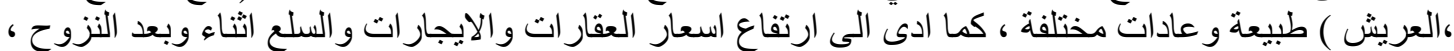

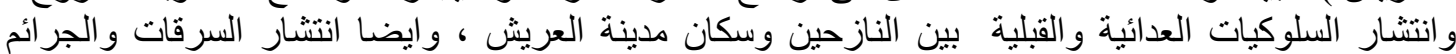
المجتمعية.

تم تجهيز كافة المدارس الحكومية في محافظة شمال سيناء بالمتطلبات الازمة للإيواء العاجل تحسبا واستعدادا

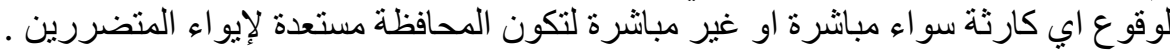

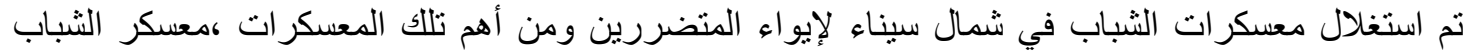

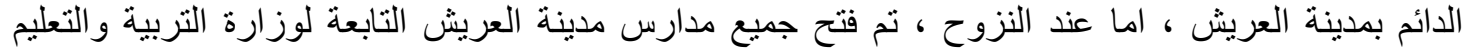

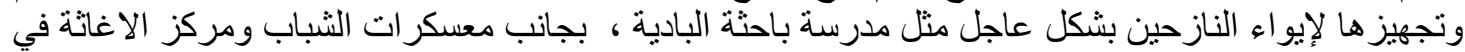
منطقة الريسة ، بالإضافة لتوفير وحدات سكنية في الإزئ منطقة العبور و السبيل .

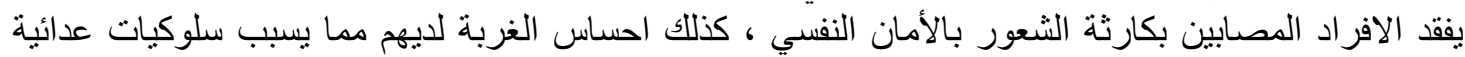

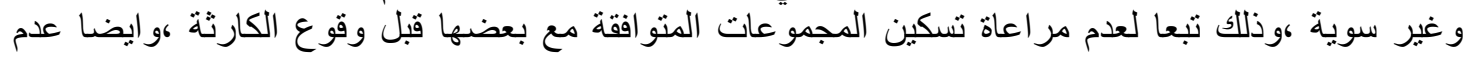

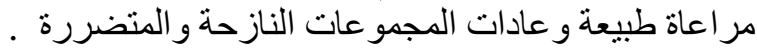

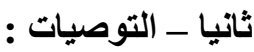

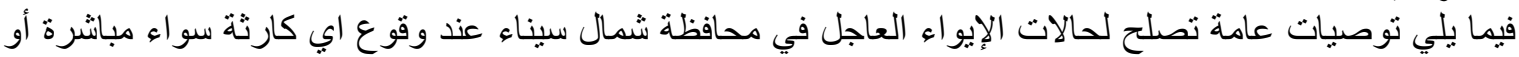

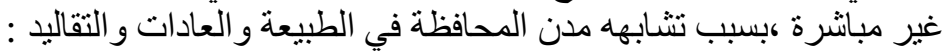

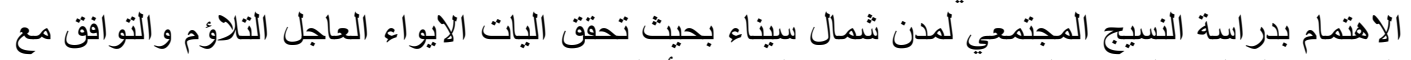

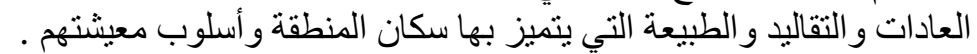

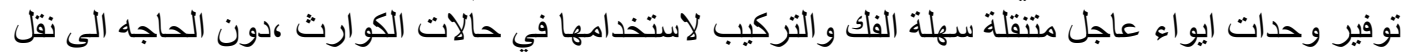

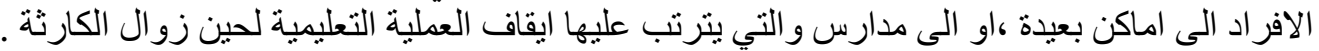

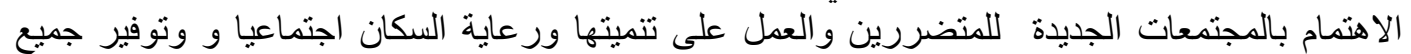

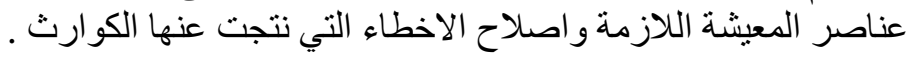

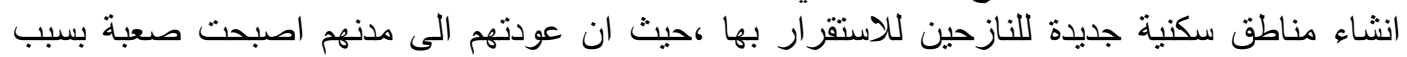

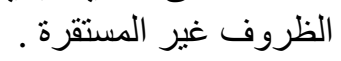
الاهتمام بالمشكلات المجتمعية والسيطرة عليها قبل تفاقمها لتصبح كارثة غير مبانشرة يترتب عليها خسائر

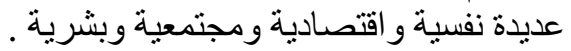

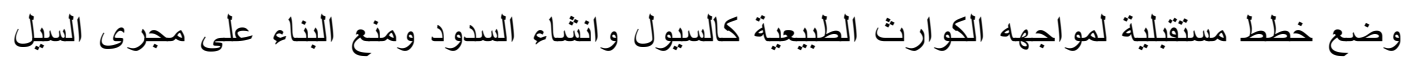

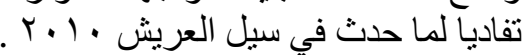
صيانه مر اكز الثباب في مدن شمال سيناء وتزوريدها بالمنطلبات اللازمة والاحتياجات لحالات الإيواء

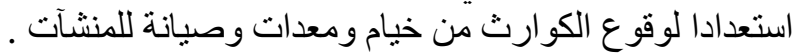

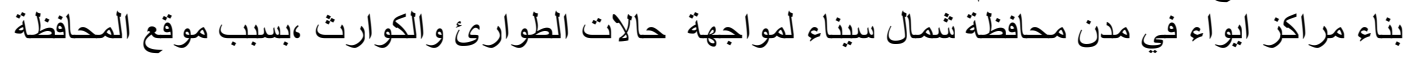

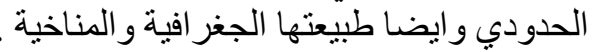

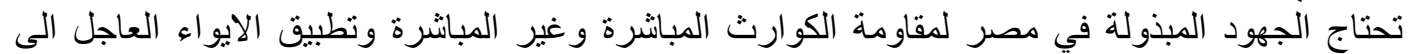

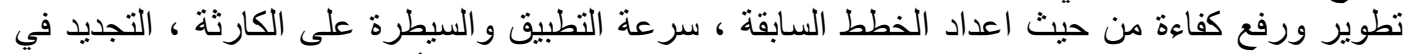

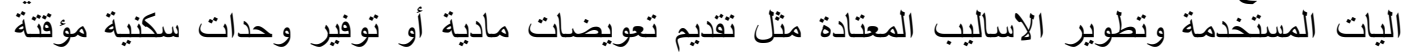
كوف غير ها. رفع الوعي المجتمعي بعملية الإيو اء العاجل و التخطيط لمو اجهه الكوارث و التنبؤ بها سواء كارثة مبانشرة أو غير مباشرة . 
يجب تحديث البيانات الخاصة بإدار ات الأزمات و الكوارث على مستوى محافظة شمال سيناء و المحافظات

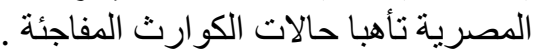

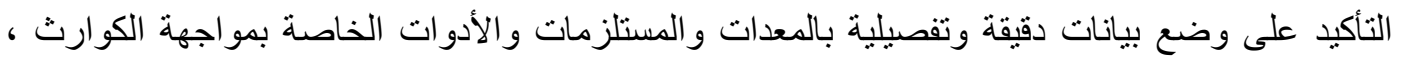

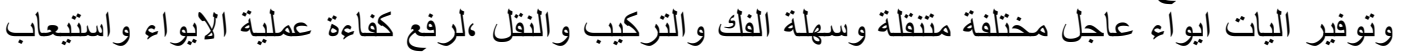
الكارثة .

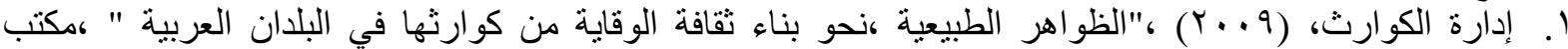

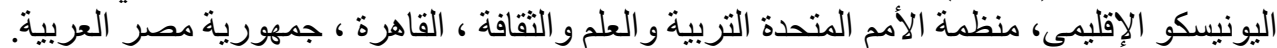

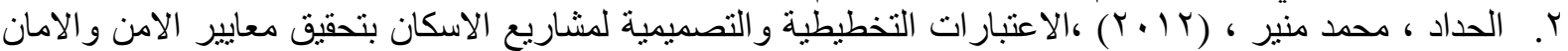

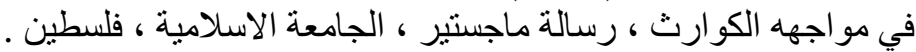

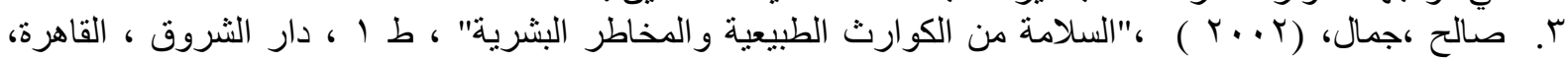

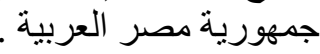

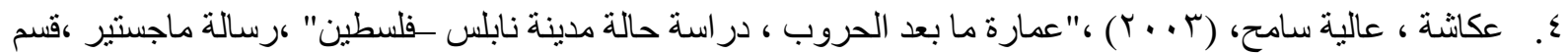

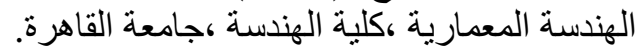

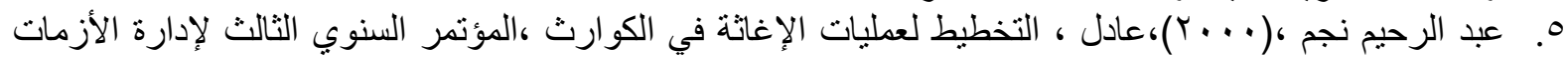

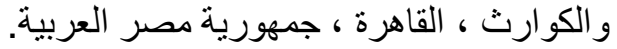

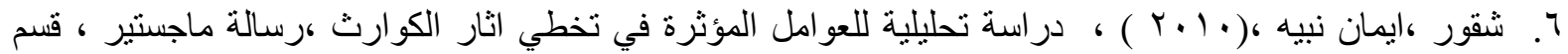

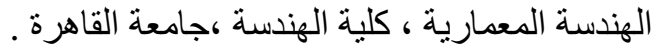

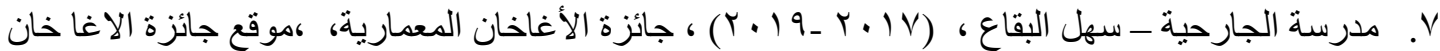

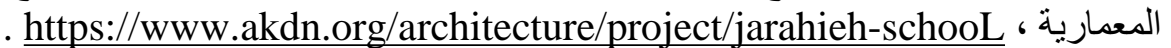

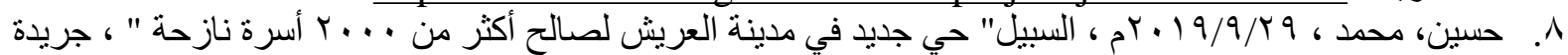

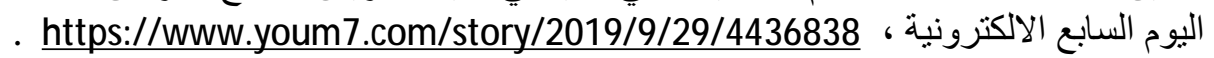

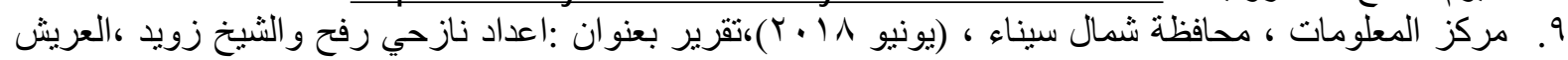
جمهورية مصر العربية.

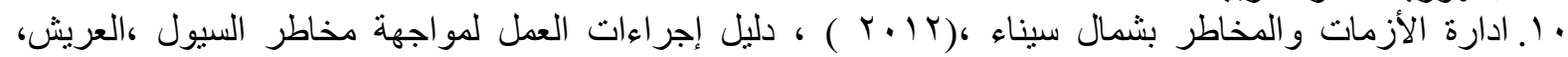
جمهورية مصر العربية.

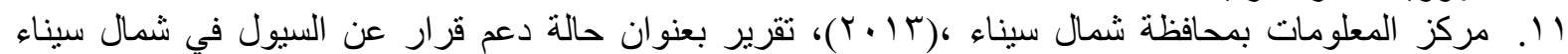
و وأخطار ها ، العريش، جمهورية الائ مصر العربية.

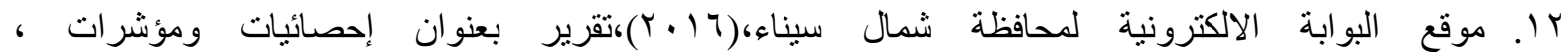
. /http://www.northsinai.gov.eg

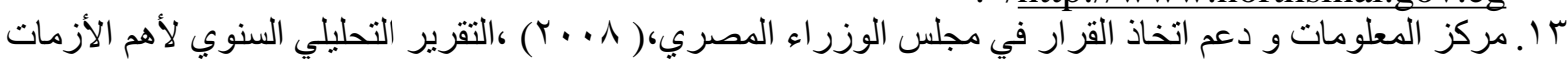

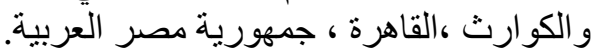

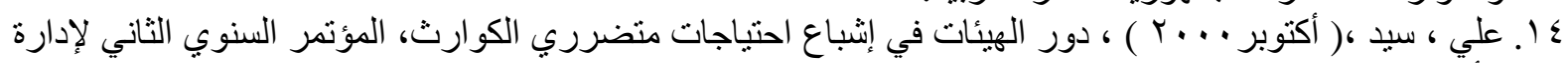

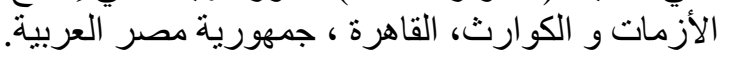

